\title{
埋め込み境界法を用いた定常の非圧縮性粘性流れのトポロジ一最適化
}

古口 睦士 ${ }^{* 1}$, 久保 世志*2 ${ }^{* 2}$ 矢地 謙太郎 ${ }^{* 3}$, 山田 崇恭 ${ }^{* 4}$, 泉井 一浩*4, 西脇 眞二*5

\section{Topology optimization method for incompressible viscous flow applying an immersed boundary method}

\author{
Atsushi KOGUCHI ${ }^{* 1}$, Seiji KUBO ${ }^{* 2}$, Kentaro YAJI ${ }^{* 3}$, \\ Takayuki YAMADA ${ }^{* 4}$, Kazuhiro IZUI $^{* 4}$ and Shinji NISHIWAKI ${ }^{* 5}$ \\ ${ }^{* 1}$ IDAJ Co., LTD. \\ The Landmark Tower Yokohama 37F, 2-2-1-1 Minatomirai, Nishi-ku, Yokohama 220-8137, Japan \\ ${ }^{* 2}$ Computational \& Mathematical Engineering Department, Research Laboratory, IHI Corporation \\ 1 Shin-Nakahara-cho, Isogo-ku, Yokohama 235-8501, Japan \\ ${ }^{* 3}$ Department of Mechanical Engineering, Graduate School of Engineering, Osaka University \\ 2-1 Yamadaoka, Suita-shi, Osaka 565-0871, Japan \\ ${ }^{*},{ }^{* 5}$ Department of Mechanical Engineering and Science, Graduate School of Engineering, Kyoto University \\ Kyoto daigaku-Katsura, Nishikyo-ku, Kyoto 615-8540, Japan
}

Received: 29 November 2017; Revised: 25 February 2018; Accepted: 2 April 2018

\begin{abstract}
This paper proposes a new topology optimization method for steady state incompressible viscous flow. Since fluid flow profiles, such as velocity and pressure profiles, describe specific behavior on walls that fluid contacts, defined boundary conditions in such profiles should be precisely evaluated. The immersed boundary method is implemented here to represent fluid flow profiles, and enhanced accuracy is obtained through their rigorous use during optimization. The topological derivative is derived for the sensitivity analysis and the finite volume method is used for numerical analysis during the optimization process. Several numerical examples are provided to confirm that the optimal configurations accurately represent flow distributions, in contrast to previous research in which a specific treatment for internal wall boundaries was not considered.
\end{abstract}

Keywords : Topology optimization, Sensitivity analysis, Topological derivative, Immersed boundary method, Level set method

1. 緒言

トポロジー最適化 (Bendsøe and Kikuchi, 1988) は，構造の形状変更のみならず，空孔の生成や消失といった形 態変化も許容する最も設計自由度が高い構造最適化の方法である. 当初, トポロジー最適化は構造問題を対象と して発展してきたが，近年では様々な物理問題に適用されており多くの革新的な最適構造が得られている.

流体力学分野への応用は, Borrvall と Petersson(Borrvall and Petersson, 2003) によってその方法論が最初に提案さ れた。この方法ではストークス流を対象として設計領域を多孔質体として仮定し, 流体領域では多孔質体の透過抵抗

No.17-00551 [DOI:10.1299/transjsme.17-00551], J-STAGE Advance Publication date : 11 April, 2018

*1 正員, (株) IDAJ（テ220-8137 神奈川県横浜市西区みなとみらい2-2-1-1 横浜ランドマークタワー37 階)

*2 正員, (株) IHI（̄235-8501 神奈川県横浜市磯子区新中原町 1)

*3 正員, 大阪大学大学院工学研究科機械工学専攻 (于565-0871 大阪府吹田市山田丘 2-1)

*4 正員, 京都大学大学院工学研究科機械理工学専攻（下615-8540 京都府京都市西京区京都大学桂）

*5 正員, フェロー, 京都大学大学院工学研究科機械理工学専攻

E-mail of corresponding author: koguchi.atsushi@idaj.co.jp 
係数を十分に小さい值とし，固体領域では透過抵抗係数に大きな值を設定することで，流体領域と固体領域を区別す ることにより，密度法に基づく最適化手法を用いて最適構造を得ている. Guest と Prévost(Guest and Prévost, 2006) は，ストークス流を対象として設計領域においてダルシー則に基づく多孔質体を定義した方法により流体領域と 固体領域を区別し, Gersborg-Hansen ら (Gersborg-Hansen et al., 2005) や Olesen ら (Olesen et al., 2006) は, この方 法をナビエ・ストークス流に拡張して密度法に基づく最適化手法により最適構造を得ている. しかしながら, こ れらの方法では, グレースケールを許容することと, 領域全体において多孔質状態を仮定しているがゆえに, 設 計領域において透過抵抗係数が滑らかに分布する構造となり, 多孔質体の透過抵抗係数の值に依っては固体領域 でも流れに起因するエネルギー散逸が生じる問題をもつ，さらに，明瞭な壁面を持たないため壁面における境界 条件を考慮できず，設計領域において最適構造に依存しない不適切な圧力場が形成される。これらの問題を解決 するために Kreissl と Maute(Kreissl and Maute, 2012) は, 流れ場の解析で eXtended Finite Element Method(XFEM) を用いることにより，壁面近傍の流れ場を厳密に表現する方法を提案している．しかしながら，この方法では流 体領域と固体領域で不連続となる流れ場を取り扱うために形状関数に新たな関数項を追加しているため離散化の 過程で複雑な手続きが必要となる.

他方, Zhou と Li(Zhou and Li, 2008) は，定常のナビエ・ストークス流を対象として，レベルセット関数を用い て境界を表現しながら最適構造を得る構造最適化の方法を提案している.この方法では, グレースケールを含まな い明膫な境界により構成された最適構造を得ることが可能となるが，形状感度に基づいてレベルセット関数を更 新する形状最適化の考え方に基づいており, 新たに空孔が生成される形態変化を行うことはできない. この問題を 解決するために Allaire ら (Allaire et al., 2005) は, 構造問題を対象として設計領域に微小な空孔を設けたときの目 的汎関数の変化率を表すトポロジー導関数を導入することで, 最適化の過程で形態変化を可能とする手法を提案 している.さらに, Challis と Guest(Challis and Guest, 2009) は，この手法をストークス流を対象とした流体問題 に展開しており, 密度法に基づく先行研究 (Borrvall and Petersson, 2003) と同様の結果が得られていることを明ら かにしている.しかしながら, この手法では最適化の過程においてトポロジー導関数に基づき空孔を生成するタイ ミングを適切に設定することが難しい問題がある.これに対して Yamada ら (Yamada et al., 2010) は, トポロジー 導関数に基づき反応拡散方程式を用いてレベルセット関数を更新し, 最適化の過程で空孔の生成が可能となるト ポロジー最適化の手法を提案している. さらに, 古口ら (古口他, 2015) や Kubo ら (Kubo et al., 2017) は, Yamada ら (Yamada et al., 2010) の手法に基づき, 流体問題を対象としてレベルセット関数による境界表現を行いながら最 適構造を得るトポロジー最適化の手法を提案している.

一般に, 最適化の過程で新たに生成された空孔の境界に対して, ディリクレ型ならびにノイマン型の境界条件の 取り扱いが必要となるが, これまでに提案された最適化の手法では, 流路構造の壁面近傍の流れ場の解析について 境界条件は一切考慮されていない.したがって, トポロジー最適化の過程で新たな空孔が生成される場合は, その 空孔の境界条件に従った壁面近傍の流れ場を厳密に評価する必要がある.この境界を厳密にモデル化するために, カットセル法 (Berger and Aftosmis, 2012)やXFEM ならびに埋め込み境界法 (Peskin, 1972) の適用が考えられる. これら中でカットセル法は, 流体領域と固体領域の壁面に沿って要素を切断することで解析領域をリメッシュす るため, 壁面近傍の要素でも保存則を満たすことが可能となる.しかしながら, 最適化の過程で形状が更新され るトポロジー最適化において, 形状更新のたびに壁面近傍の要素切断を行うカットセル法の適用は, 複雑な手続 きを新たに追加することとなり，結果として計算時間の増大が考えられる．さらに，カットセル法に基づくリメッ シュにより微小な要素やひずみの大きい要素が数多く生成されるため, 結果として計算の不安定性が生じると考 えられる.これに対して埋め込み境界法は, 壁面近傍の要素で保存則が満たされないこともあるが, 流体領域と 固体領域の境界適合格子を必要としない流れ場の解析が可能である. したがって, 最適化の過程で流路構造の形 態が大きく変化しても解析格子の再構築が不要であるためトポロジー最適化には非常に有効な境界のモデル化手 法と考えられる．また，XFEMによる壁面の取り扱いでは形状関数に新たな関数項が必要となるが，埋め込み境 界法は, 有限要素法や有限体積法における状態方程式の離散化の過程で特別な手続きは必要とせず，実装が容易 であるという利点がある.

そこで，本論文では定常の非圧縮性粘性流れを対象として，レベルセット法による流路構造の境界表現を行い ながら, 流体領域と固体領域の境界において埋め込み境界法により壁面近傍の流れ場を決定し, 感度解析にはト ポロジー導関数を適用する新しいトポロジー最適化の手法を提案する.この手法により, 最適構造における領域 
内部の流れ場を正しく計算することが可能となる. 状態方程式ならび随伴方程式は, 古口ら (古口他, 2015) の手法 に従って有限体積法により離散化し, 数值解析には Semi-Implicit Method for Pressure Linked Equation 法 (SIMPLE 法 $)($ Patanker, 1980) を適用する.また，レベルセット関数の更新には Yamada ら (Yamada et al., 2010)により提案 された時間発展方程式を適用し，その数值解析の手法にはオイラー陰解法を採用する. 以下，2 章では最適化問題 について述べる. 3 章では埋め込み境界法について説明し，4 章では最適化のアルゴリズムについて説明する．5 章で数值計算例を示して提案する手法の妥当性を検証し，6章で結言とする.

\section{2. 最適化問題の定式化}

\section{$2 \cdot 1$ 非圧縮性粘性流れの支配方程式}

流体で満たされた領域を $\Omega \subset \mathbb{R}^{d}(d=2,3)$ として, 位置 $\boldsymbol{x} \in \Omega$ での流速を $\boldsymbol{u}$, 静圧を $p$, 動粘性係数を $v$, 外力 を $\boldsymbol{f}$ とする. ディリクレ型境界条件として流速が $\boldsymbol{u}=\boldsymbol{u}_{0}$ に規定されている境界を $\Gamma_{D}$, 流出境界条件として一般 的に用いられるノイマン型境界条件が定義された境界を $\Gamma_{N}$ とすると, 領域 $\Omega$ においてニュートン流体による非 圧縮性粘性流れの支配方程式は次式で表すことができる.

$$
\begin{array}{ll}
(\boldsymbol{u} \cdot \nabla) \boldsymbol{u}+\nabla p-\nabla \cdot(2 v \boldsymbol{C}(\boldsymbol{u}))-\boldsymbol{f}=\mathbf{0} & \text { in } \Omega \\
-\nabla \cdot \boldsymbol{u}=0 & \text { in } \Omega \\
\boldsymbol{u}=\boldsymbol{u}_{0} & \text { on } \Gamma_{D} \\
(-p \boldsymbol{I}+2 v \boldsymbol{C}(\boldsymbol{u})) \cdot \boldsymbol{n}=0 & \text { on } \Gamma_{N}
\end{array}
$$

ここで, $\boldsymbol{I}$ は単位行列, $\boldsymbol{n}$ は境界 $\Gamma=\partial \Omega \subset\left(\Gamma_{D} \cup \Gamma_{N}\right)$ における外向き単位法線ベクトルを表す.また, $\boldsymbol{C}(\boldsymbol{u})$ は, 次 式により定義されるひずみ速度テンソルを表す.

$$
\boldsymbol{C}(\boldsymbol{u})=\frac{1}{2}\left(\nabla \boldsymbol{u}+(\nabla \boldsymbol{u})^{T}\right)
$$

\section{$2 \cdot 2$ 流体力学の問題とトポロジー最適化}

流体力学を対象としたトポロジー最適化では, 図 1(a)に示すように固定された設計領域 $D$ (以下, 固定設計領域 $D ） に$ 対して, ある制約条件の下で目的汎関数值を最小または最大にする流体領域 $\Omega$ を求める問題となる. 先行 研究 (Borrvall and Petersson, 2003) において提案されている手法では, 固定設計領域 $D$ を多孔質体として仮定し, 透過抵抗係数 $\alpha$ を設計変数として固体領域 $D \backslash \Omega$ において流速が 0 となるように仮想的な外力 $\boldsymbol{f}=-\alpha \boldsymbol{u}$ を与える ことで固体領域を陰的に表現する。これにより得られる流速は図 1(b)のように分布し, 静圧は図 1(c) のように分 布する.ここで, 流れ場のそれぞれの分布図において最適構造の境界は白色の点線で示す.

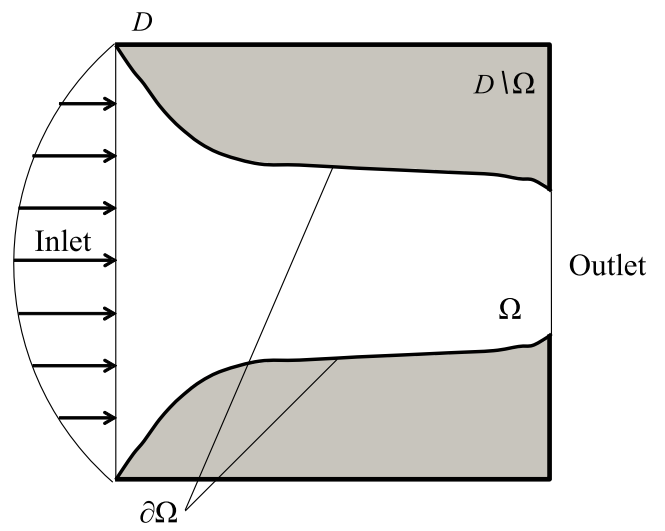

(a) Optimized configuration

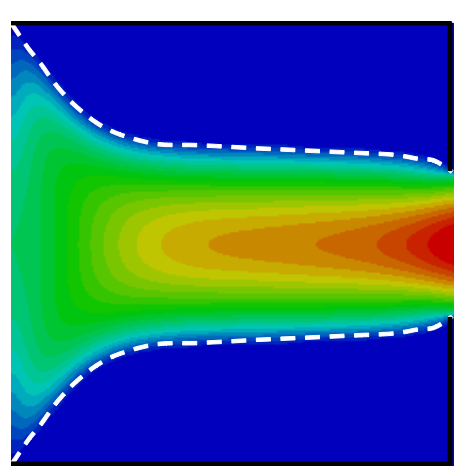

(b) Velocity magnitude

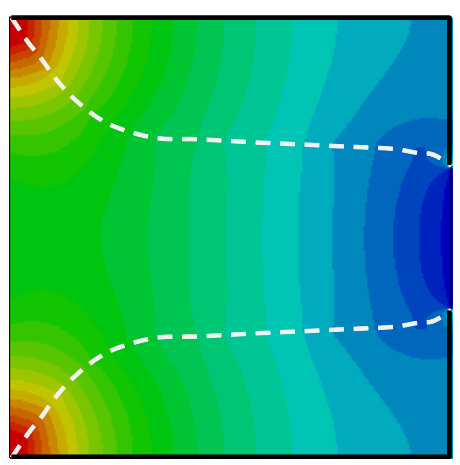

(c) Static pressure

Fig. 1 Typical example of fluid topology optimization 
この手法により流路構造の壁面近傍で流速は 0 に漸近するが, その一方で, 図 $1(\mathrm{c})$ に示すように静圧が固体領 域にも分布する流れ場となる．すなわち，固体領域に仮想的な外力を与える手法では流路構造の壁面において境 界条件を定義できないため, 固体領域に対しても流れ場に起因した静圧分布となる. また, 流路構造の壁面にお ける流速の滑り境界も定義できないため最適化の対象となる流れ場が限定されるという久点がある.

流体力学の問題では，壁面近傍の取り扱いが厳密で流れ場全体に影響を及ぼすことが多い．特に乱流を考慮す る場合には壁面近傍の流れ場が壁法則に支配され解析対象の流れ場に大きな影響を与える. そこで流路構造の壁 面近傍の流れ場を正確に取り扱えない先行研究の手法の問題を克服するために，流路構造の壁面における境界条 件の考慮を可能とした埋め込み境界法による最適化の手法を構築する.

\section{$2 \cdot 3$ レベルセット法に基づく境界表現}

固定設計領域 $D$ において $\phi: D \rightarrow \mathbb{R}$ の零等位面によって境界 $\partial \Omega$ を表現する. ここで, 流体領域を $\Omega$, 固体領 域を $D \backslash \Omega$ とするとレベルセット関数 $\phi(x)$ は次式で表すことができる.

$$
\begin{cases}0<\phi(x) \leqslant 1 & \text { for } x \in \Omega \backslash \partial \Omega \\ \phi(x)=0 & \text { for } x \in \partial \Omega \\ -1 \leqslant \phi(x)<0 & \text { for } x \in D \backslash \Omega\end{cases}
$$

すなわち, レベルセット関数 $\phi(x)$ の值は流体領域では正の值をとり, 固体領域では負の值をとる. 零等位面は流 体領域と固体領域の境界 $\partial \Omega$ を表す。また，ここでは後述する正則化の手続きのためにレベルセット関数值の上限 值と下限值に制約を与えているが，零等位面以外のレベルセット関数值にも任意性が存在するため，このような 制約を与えても問題は生じない.

\section{4 全圧損失最小化問題}

本論文では, 固定設計領域 $D$ における境界 $\partial D$ での圧力差に起因した次式で表される全圧損失 $J(\boldsymbol{u}, p)$ の最小化 問題を考える.

$$
J(\boldsymbol{u}, p)=-\int_{\partial D}\left(\left(p+\frac{1}{2} \boldsymbol{u} \cdot \boldsymbol{u}\right) \boldsymbol{u} \cdot \boldsymbol{n}\right) \mathrm{d} \Gamma
$$

式 (7) を目的汎関数として全圧損失最小化問題は次式にように定式化できる.

$$
\begin{aligned}
& \inf _{\phi} J=J(\boldsymbol{u}, p) \\
& \text { subject to } G=\int_{D} \chi_{\phi} \mathrm{d} D-G_{\max } \leqslant 0
\end{aligned}
$$

ここで流速 $\boldsymbol{u}$ と静圧 $p$ は式 (3) ならびに式 (4) で示す境界条件の下で, 式 (1) で定義されたナビエ・ストークス方 程式ならびに式 (2) で定義された連続の式を満たす。なお, これ以降では式 (1) のナビエ・ストークス方程式にお ける外力項は $\boldsymbol{f}=\mathbf{0}$ として扱う. また, $G$ は固定設計領域 $D$ において上限值を $G_{\max }$ として許容される流体領域 の不等式制約を表す. $\chi_{\phi}$ は流体領域において正值, 固体領域において零をとる特性関数でありレベルセット関数 $\phi(x)$ を用いて次式で定義する.

$$
\chi_{\phi}(\phi)= \begin{cases}1 & \text { if } \quad \phi(x) \geqslant 0 \\ 0 & \text { if } \quad \phi(x)<0\end{cases}
$$

次に最適化問題の正則化を行う. トポロジー最適化の問題は流路の有無を特性関数により表現する. このため, 固 定設計領域 $D$ の内部で不連続な状態を持つ不適切な問題となる. そこで本論文では, この問題を解決するために, 目的沉関数と正則化項の和を用いることで最適化の問題を置き換え正則化する (Yamada et al., 2010). 正則化項を $R_{\tau}(\phi)$ として正則化された目的沉関数 $J_{R}$ は次式により定義できる.

$$
J_{R}=J(\boldsymbol{u}, p)+R_{\tau}(\phi)
$$


ここで正則化項 $R_{\tau}(\phi)$ は正則化係数 $\tau>0$ を用いて次式のように定義される.

$$
R_{\tau}(\phi)=\frac{1}{2} \tau \int_{D}|\nabla \phi|^{2} \mathrm{~d} D
$$

したがって，本論文では式(8)を式(13)のように置き換えることで最適化問題の正則化を行う.

$$
\begin{aligned}
& \inf _{\phi} J_{R}=J(\boldsymbol{u}, p)+R_{\tau}(\phi) \\
& \text { subject to } G=\int_{D} \chi_{\phi} \mathrm{d} D-G_{\max } \leqslant 0
\end{aligned}
$$

以上の最適化問題の正則化により, レベルセット関数の值は, 式 (6) に示すように上限值ならびに下限值に制約を 与えているため, 式 (13) で定義される目的汎関数 $J_{R}$ に対してレベルセット関数の遷移幅が同じ場合には, 正則化 項の効果を同等に寄与させることができる.すなわち，レベルセット関数の值に制約を与えることで，正則化項 の過剩な寄与を回避できる.

\section{$2 \cdot 5$ 最適化問題の解法}

本論文では最適構造を得る手法としてラグランジュ未定乗数法を適用する．ラグランジュ未定乗数法は最適化問 題の解析手法のひとつである. 目的汎関数に対してラグランジュ未定乗数 $\lambda$ を乗じた制約条件の項を追加し, 次 式に示すラグランジュ汎関数 $L_{R}$ を定義する．そして，ラグランジュ汎関数 $L_{R}$ の停留值問題を解くことで最適構 造を計算する.

$$
L_{R}=L+R_{\tau}(\phi)
$$

ここで，式(15) における右辺第 1 項の $L$ は $\lambda \geqslant 0$ となるラグランジュ未定乗数を用いて次式で定義する.

$$
L=J(\boldsymbol{u}, p)+A\left(\boldsymbol{u}, \boldsymbol{u}_{a}, p\right)+B\left(\boldsymbol{u}, p_{a}\right)+\lambda G
$$

また，ソボレフ空間 $H^{1}(D)$ およびルベーグ空間 $L^{2}(D)$ で定義される試行関数 $\left(\boldsymbol{u}_{a}, p_{a}\right) \in H^{1}(D) \times L^{2}(D)$ を用いて $A\left(\boldsymbol{u}, \boldsymbol{u}_{a}, p\right)$ ならびに $B\left(\boldsymbol{u}, p_{a}\right)$ をそれぞれ次式により定義する.

$$
\begin{aligned}
& A\left(\boldsymbol{u}, \boldsymbol{u}_{a}, p\right)=\int_{D} \boldsymbol{u}_{a} \cdot(\boldsymbol{u} \cdot \nabla) \boldsymbol{u} \mathrm{d} D+\int_{D} \boldsymbol{u}_{a} \nabla p \mathrm{~d} D-\int_{D} \boldsymbol{u}_{a} \nabla \cdot(2 v \boldsymbol{C}(\boldsymbol{u})) \mathrm{d} D \\
& B\left(\boldsymbol{u}, p_{a}\right)=-\int_{D} p_{a} \nabla \cdot \boldsymbol{u} \mathrm{d} D
\end{aligned}
$$

式 (15) の停留值が最適解となるが，このとき最適解は次式で表される Karush-Kuhn-Tucker(KKT) 条件を満たす.

$$
\delta L_{R}=0, \quad \lambda G=0, \quad \lambda \geqslant 0, \quad G \leqslant 0
$$

KKT 条件を満たす $\phi$ が最適解の候補となる. しかしながら，式(19) より最適解を直接求めるのは困難である.そ こで最適解を探索するために, 初期值として $\phi$ に適当な值を与え, 仮想時間 $t_{v}$ ならびに $K>0$ となる比例定数 $K$ を導入し，次式に示す $\phi$ に関する時間発展問題に置き換えることで最適解を得る.

$$
\frac{\partial \phi}{\partial t_{v}}+K L_{R}{ }^{\prime}=0
$$

式 (20)における $L_{R}{ }^{\prime}$ はラグランジュ汎関数 $L_{R}$ の勾配であり, 時間発展の駆動力は $\phi$ に関するラグランジュ汎関 数 $L_{R}$ の勾配 $L_{R}{ }^{\prime}$ に比例すると仮定する (Yamada et al., 2010). また, 式(15) より $L_{R}{ }^{\prime}=L^{\prime}-\tau \nabla^{2} \phi$ となり, さらに, 式 (20) の境界条件として流体領域と固体領域を指定するディリクレ型境界条件を与えることで，次式に示す正則 化項を考慮した時間発展方程式を得る.

$$
\begin{array}{ll}
\frac{\partial \phi}{\partial t_{v}}+K\left(L^{\prime}-\tau \nabla^{2} \phi\right)=0 & \text { in } D \\
\phi=-1 & \text { on } \partial D \backslash \partial D_{N D} \\
\phi=1 & \text { on } \partial D_{N D}
\end{array}
$$

なお， $L^{\prime}$ は後述するトポロジー導関数を考慮することで決定される．ここで， $\partial D_{N D}$ は固定設計領域 $D$ の境界 $\partial D$ における流入ならび流出境界であり非設計領域境界とする. 式 (22) ならびに式 (23) の境界条件のもとで式 (21)に より流路構造を表すレベルセット関数 $\phi$ を計算する. 


\section{6 感度解析}

トポロジー導関数は, 流体領域 $\Omega$ において微小な空孔を生成した時の目的汎関数の勾配として定義される.十 分に滑らかな境界 $\partial \Omega$ を持つ流体領域 $\Omega \subset \mathbb{R}^{d}$ において，位置 $x \in \Omega$ を中心として実数 $\varepsilon>0$ なる半径 $\varepsilon$ の空孔 $\Omega_{\varepsilon}=\{\boldsymbol{y} \in \varepsilon\|\boldsymbol{y}-\boldsymbol{x}\|<\varepsilon\}$ により，目的汎関数 $J(\Omega)$ が位相的に捸動するとき次式のように漸近展開できる.

$$
J\left(\Omega \backslash \overline{\Omega_{\varepsilon}}\right)=J(\Omega)+f(\varepsilon) D_{T} J(\boldsymbol{x})+o(\varepsilon)
$$

ここで $\overline{\Omega_{\varepsilon}}$ は $\Omega_{\varepsilon}$ の閉包であり, $f(\varepsilon)$ は $f(\varepsilon)>0$ かつ $\varepsilon \rightarrow 0$ のとき $f(\varepsilon) \rightarrow 0$ となる関数とする. このとき $D_{T} J(\boldsymbol{x})$ を位置 $\boldsymbol{x}$ における $J$ に関するトポロジー導関数と呼び, ルベーグ測度 $\left|\overline{\Omega_{\varepsilon}}\right|$ を用いて次式により表される.

$$
D_{T} J(\boldsymbol{x})=\lim _{\varepsilon \rightarrow 0} \frac{J\left(\Omega \backslash \overline{\Omega_{\varepsilon}}\right)-J(\Omega)}{\left|\overline{\Omega_{\varepsilon}}\right|}
$$

支配方程式にナビエ・ストークス方程式を適用したトポロジー導関数は, Amstutz(Amstutz, 2005) ならびに Deng ら (Deng et al., 2013)により導出されており次式で表される.

$$
L^{\prime}= \begin{cases}4 \pi v \boldsymbol{u} \cdot \boldsymbol{u}_{a}+\pi \lambda & \text { in } 2 D \\ 6 \pi v \boldsymbol{u} \cdot \boldsymbol{u}_{a}+\frac{4}{3} \pi \lambda & \text { in } 3 D\end{cases}
$$

ここで $\boldsymbol{u}_{a}$ ならびに $p_{a}$ は, $(\boldsymbol{\delta} \boldsymbol{u}, \delta p) \in H^{1}(D) \times L^{2}(D)$ を試行関数として，次式に示す随伴方程式を満たす.

$$
\begin{aligned}
& \bar{J}_{\boldsymbol{u}^{\prime}}=\int_{D} \boldsymbol{u}_{a} \cdot((\boldsymbol{\delta} \boldsymbol{u} \cdot \nabla) \boldsymbol{u}+(\boldsymbol{u} \cdot \nabla) \delta \boldsymbol{u}) \mathrm{d} D-\int_{D} \boldsymbol{u}_{a} \nabla \cdot(2 \boldsymbol{v} \boldsymbol{C}(\boldsymbol{\delta} \boldsymbol{u})) \mathrm{d} D-\int_{D} p_{a} \nabla \cdot \boldsymbol{\delta} \boldsymbol{u} \mathrm{d} D=0 \\
& \bar{J}_{p^{\prime}}=-\int_{D} \boldsymbol{\delta} p \nabla \cdot \boldsymbol{u}_{a} \mathrm{~d} D=0
\end{aligned}
$$

式 (26) に示す設計感度 $L^{\prime}$ を式 (21)に代入し，次式の時間発展方程式を得る.

$$
\frac{\partial \phi}{\partial t_{v}}= \begin{cases}-K\left(4 \pi v \boldsymbol{u} \cdot \boldsymbol{u}_{a}+\pi \lambda-\tau \nabla^{2} \phi\right) & \text { in } 2 D \\ -K\left(6 \pi v \boldsymbol{u} \cdot \boldsymbol{u}_{a}+\frac{4}{3} \pi \lambda-\tau \nabla^{2} \phi\right) & \text { in } 3 D\end{cases}
$$

\section{3.レベルセット法と埋め込み境界法}

埋め込み境界法は, 壁面に沿った境界適合格子を必要とせずに直交格子の領域内に流路構造を配置した 流れ場の解析が可能な手法であり, Contiuous forcing approach と Discrete forcing approachに大別される (Mittal and Iaccarino, 2005). Continuous forcing approach は, 状態方程式の外力項に仮想的な力を加えることで 壁面近傍の流れ場を近似的に計算する。しかしながら，この手法は実装が複雑であり，かつ外力項を制御するパ ラメータの調整が難しく状態方程式の数值計算も不安定になる傾向がある。一方で, Discrete forcing approachの 1 つであるゴーストセル法 (Majumdar et al., 2001) は，壁面の境界条件を満たすように補間関数を決定し，その補 間関数を用いて壁面近傍の流れ場を計算する.この手法では, 壁面近傍の流れ場の解析と状態方程式の数值解法 が独立しているため実装が容易であり，壁面近傍の流れ場は補間関数より求められるので数值計算も安定してい る。そこで本論文ではゴーストセル法に基づく埋め込み境界法を適用する.

次に，流路構造の壁面を表すレベルセット関数の零等位面で定義された流速 $\boldsymbol{u}$ ならびに静圧 $p$ の境界条件を考 える，零等位面に定義された境界条件を数值計算で直接考慮することは不可能であるため，境界条件として定義 された物理值を零等位面と交差または隣接する要素へ写像する.すなわち，レベルセット関数 $\phi(x)$ の零等位面の 近傍の要素を IB 要素として抽出し, IB 要素の中心座標から予め定めた範囲内に存在する近傍要素 (図 2(b) に示す Near cells) の物理值 $\Theta$ ならびに境界条件を考慮して最小二乗法により IB 要素の補間関数を決定する。なお IB 要 素は零等位面と交差または隣接し，かつレベルセット関数 $\phi(x)>0$ となる要素と定義する (図 $2(a))$.

最後に補間関数について考える. 支配方程式 (1)(2)における流速 $\boldsymbol{u}$ ならびに静圧 $p$ は高々 2 階の微分可能な関数 で近似が可能であるため, 補間関数は, 境界 $\Gamma_{i b D}$ で定義されたディリクレ型ならびに境界 $\Gamma_{i b N}$ において定義され たノイマン型の境界条件に対して次式に示す 2 次多項式として定義する.

$$
\begin{aligned}
& \Theta(\boldsymbol{X})=E_{0}+\boldsymbol{E}_{1} \cdot \boldsymbol{X}+\boldsymbol{X}^{T} \boldsymbol{E}_{2} \boldsymbol{X} \text { for } \Gamma_{i b D} \\
& \Theta(\hat{\boldsymbol{x}})=F_{0}+\boldsymbol{F}_{1} \cdot \hat{\boldsymbol{x}}+(\hat{\boldsymbol{x}})^{T} \boldsymbol{F}_{2} \hat{\boldsymbol{x}} \text { for } \Gamma_{i b N}
\end{aligned}
$$


ここで, $E_{0}, F_{0}$ はスカラー, $\boldsymbol{E}_{1}, \boldsymbol{F}_{1}$ はベクトル, $\boldsymbol{E}_{2}, \boldsymbol{F}_{2}$ は 2 階のテンソルとなる. また，図 $2(\mathrm{~b})$ に示すように, $x_{0}$ はレベルセット関数の零等位面上の点を表し， $x_{i b}$ は IB 要素の中心座標を表す. 多くの場合，IB 要素の中心座 標 $\boldsymbol{x}_{i b}$ は零等位面上に存在しないため, 式 (30) ならびに式 (31) で表される補間関数を決定するために零等位面上 の点 $x_{0}$ を計算する必要がある. 零等位面上の点 $x_{0}$ は, レベルセット関数が陰関数として定義されるスカラー関数 であるため, IB 要素の中心座標 $x_{i b}$ とレベルセット関数值 $\phi$ ならびに，その勾配 $\nabla \phi$ を用いて次式により計算が 可能となる.

$$
\boldsymbol{x}_{0}=\boldsymbol{x}_{i b}-\frac{\nabla \phi\left(\boldsymbol{x}_{i b}\right)}{\left|\nabla \phi\left(\boldsymbol{x}_{i b}\right)\right|^{2}} \phi\left(\boldsymbol{x}_{i b}\right)
$$

また, 式 (30) における $\boldsymbol{X}$ は, 零等位面上の点 $\boldsymbol{x}_{0}$ を用いて $\boldsymbol{X}=\boldsymbol{x}-\boldsymbol{x}_{0}$ と定義する. これにより $\boldsymbol{X}=\mathbf{0}$ は零等位面 上の点となるため, $E_{0}$ は零等位面上に定義されたディリクレ型境界条件の值と同等になる.したがって，式 (30) は零等位面上で定義されたディリクレ型境界条件を満たした補間関数となる.

さらに, 式 (31) で表される補間関数は, 零等位面の点 $\boldsymbol{x}_{0}$ を原点とし，その法線ベクトル $\boldsymbol{n}$ を基底ベクトルとし た局所座標系 $\hat{\boldsymbol{x}}$ により定義する. すなわち，局所座標系 $\hat{\boldsymbol{x}}$ の基底べクトルのひとつである $\hat{\boldsymbol{x}}_{2}$ を, 図 2(b)に示すよ うに零等位面の法線 $\boldsymbol{n}$ と同じ方向とし，局所座標系 $\hat{\boldsymbol{x}}$ において $\hat{\boldsymbol{x}}=\mathbf{0}$ は零等位面上の点とする.これにより，境界 $\Gamma_{i b N}$ で定義される物理值 $\Theta$ の勾配 $C$ 対して, レベルセット関数の零等位面の法線ベクトル $\boldsymbol{n}$ を用いて $\nabla \Theta(\mathbf{0}) \cdot \boldsymbol{n}=C$ を満たすように係数 $\boldsymbol{F}_{1}$ を決定することで，式 (31) は零等位面上で定義されたノイマン型境界条件を満たした補 間関数となる.

本論文では, 零等位面において流速 $\boldsymbol{u}=\mathbf{0}$ のディリクレ型境界条件を定義し, 静圧 $p$ は $\nabla p \cdot \boldsymbol{n}=0$ のノイマン型 境界条件を定義する。これにより IB 要素の中心座標における流速 $\boldsymbol{u}$ ならびに静圧 $p$ は, 次式で計算が可能となる.

$$
\begin{aligned}
\boldsymbol{u}\left(\boldsymbol{X}_{i b}\right) & =\boldsymbol{E}_{1} \cdot \boldsymbol{X}_{i b}+\boldsymbol{X}_{i b}^{T} \boldsymbol{E}_{2} \boldsymbol{X}_{i b} & & \text { for } \Gamma_{i b D} \\
p\left(\hat{\boldsymbol{x}}_{i b}\right) & =F_{0}+\boldsymbol{F}_{1} \cdot \hat{\boldsymbol{x}}_{i b}+\left(\hat{\boldsymbol{x}}_{i b}\right)^{T} \boldsymbol{F}_{2} \hat{\boldsymbol{x}}_{i b} & & \text { for } \Gamma_{i b N}
\end{aligned}
$$

ここで $\boldsymbol{X}_{i b}=\boldsymbol{x}_{i b}-\boldsymbol{x}_{0}$ とし， $\hat{\boldsymbol{x}}_{i b}$ は局所座標系 $\hat{\boldsymbol{x}}$ 上の IB 要素の中心座標とする. まとめとして, IB 要素における埋 め込み境界法を用いた物理值の計算手順を以下に示す.

Step1 零等位面と交差または隣接し, 要素の中心座標におけるレベルセット関数が $\phi(x)>0$ となる要素を IB 要 素として抽出する.

Step2 IB 要素の中心座標 $x_{i b}$ に対して式 (32) を用いて零等位面上の座標 $x_{0}$ を計算する.

Step3 IB 要素に対してディリクレ型境界条件を考慮して係数 $E_{0}$ を決定し，ノイマン型境界条件を考慮して係数 $\boldsymbol{F}_{1}$ を決定する.

Step4 IB 要素に対して予め定めた範囲内の近傍要素を抽出する.

Step5 IB 要素に対して近傍要素の物理值を用いて補間関数の係数 $\boldsymbol{E}_{1}, \boldsymbol{E}_{2}, F_{0}, \boldsymbol{F}_{2}$ を最小二乗法により決定する.

Step6 Step5 で求めた補間関数を用いて, IB 要素の中心座標 $\boldsymbol{x}_{i b}$ における物理值を決定する.

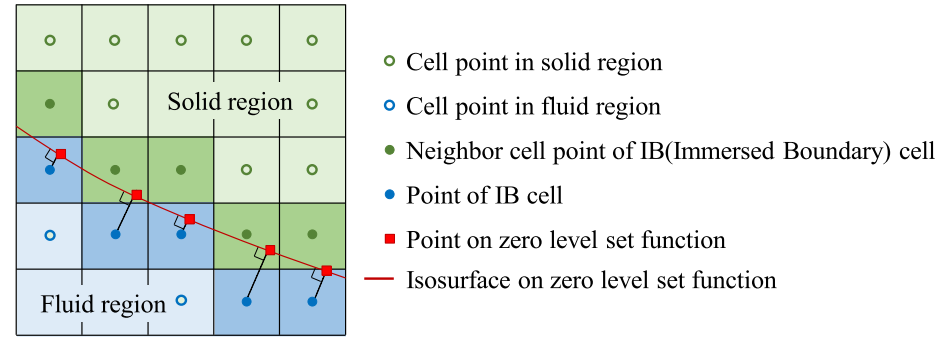

(a) Immersed boundary method with IB cell

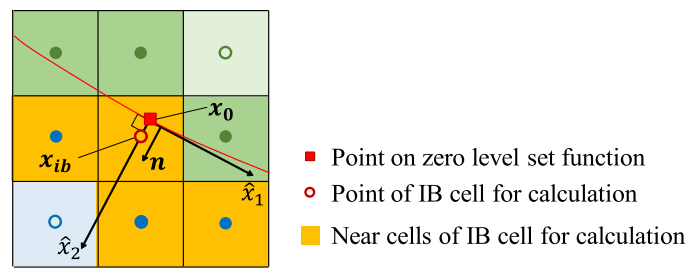

(b) IB cell for calculation

Fig. 2 Schematic diagram of immersed boundary method 


\section{4. 最適化のアルゴリズム}

本章では，埋め込み境界法による零等位面の境界条件を考慮した最適化のアルゴリズムについて説明する．す でに緒言で述べた通り，埋め込み境界法は，IB 要素での保存則を満たすのが困難である．そこで，IB 要素におい て保存則を満たすように体積流量の補正を考える. 本論文で提案する手法では, SIMPLE 法による流れ場の数值解 析法に埋め込み境界法を適用する. SIMPLE 法は, 流速ならびに静圧の予測值を用いてナビエ・ストークス方程式 と連続の式を分離して反復的に解く数值解析法である. はじめに埋め込み境界法により IB 要素における境界条件 を決定し，圧力の予測值 $p^{\prime}$ を用いてナビエ・ストークス方程式を満たす流速の予測值 $\boldsymbol{u}^{\prime}$ を求める. 次に, IB 要 素において体積流量が保存されるように補正する。体積流量は, 要素面の面積と流速により決定されるため, IB 要素において非圧縮性流れの保存則を満たすように流速を補正することと同等である. さらに，流速の予測值 $\boldsymbol{u}^{\prime}$ の発散を求め, 連続の式を満たすように解くことで圧力を補正する。これ以降は SIMPLE 法の手続きに従い，反 復計算により流れ場を計算する。

以下では，最適化アルゴリズムについて説明する．また，最適化アルゴリズムのフローチャートを図 3 に示す. はじめに, 適当な流路の初期構造を与えるために固定設計領域 $D$ にレベルセット関数 $\phi(x)$ の初期值を設定する. 次に, レベルセット関数 $\phi(x)$ の零等位面から IB 要素を抽出し, 零等位面の境界条件を考虑して IB 要素の状態場 を決定する．IB 要素の状態場を境界条件として，有限体積法により離散化された状態方程式ならびに随伴方程式 を SIMPLE 法により解き，状態場 $(\boldsymbol{u}, p)$ ならびに随伴場 $\left(\boldsymbol{u}_{a}, p_{a}\right)$ を得る. 得られた流速 $\boldsymbol{u}$ と随伴流速 $\boldsymbol{u}_{a}$ から感度 解析を行い，求めた感度を用いてレベルセット関数を更新する。この手続きを目的汎関数の值が収束するまで反 復する。

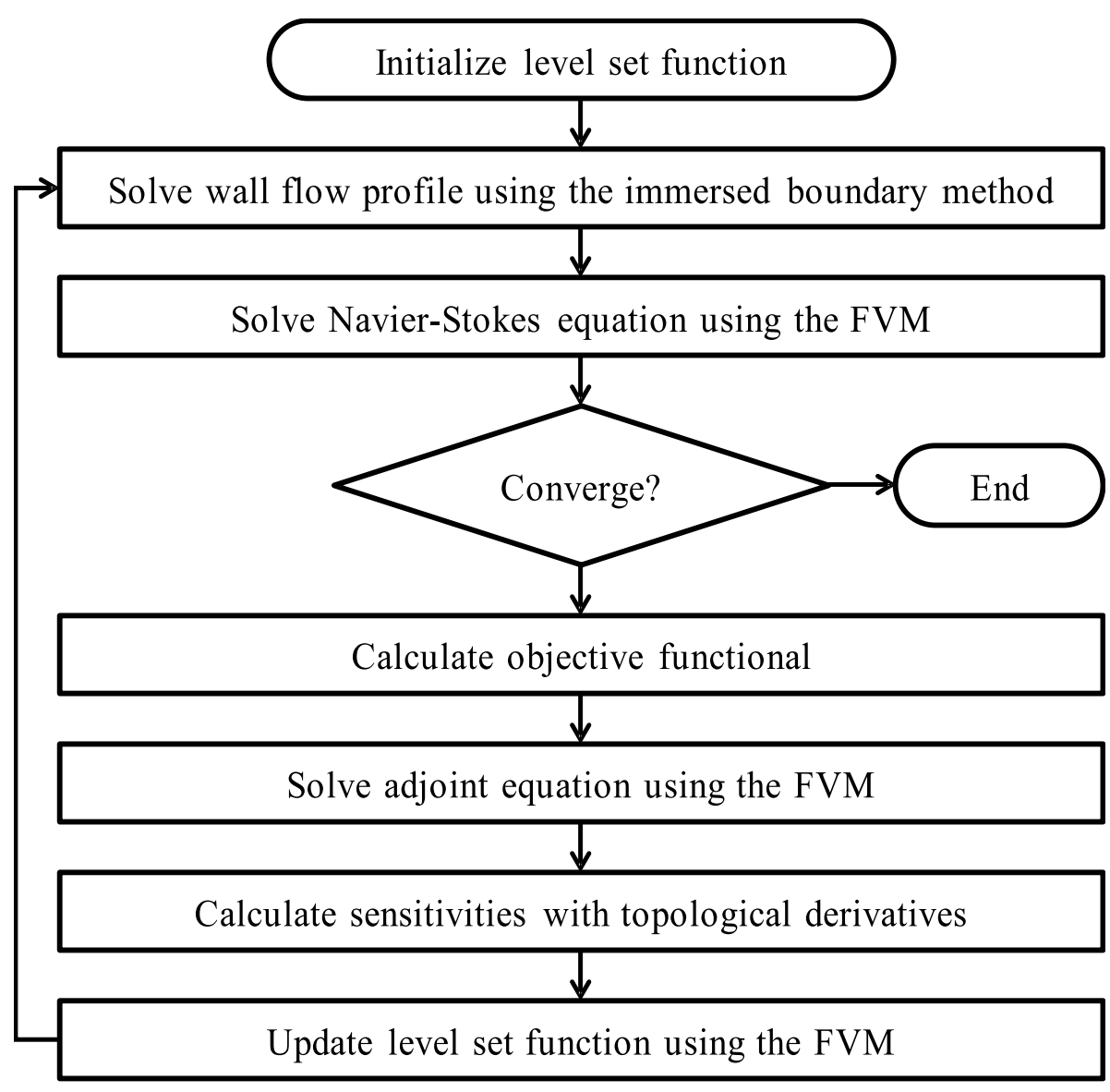

Fig. 3 Flow chart of the proposed method 


\section{5. 数 值 計 算 例}

\section{$5 \cdot 1$ 数值計算例の概要}

本章では数值計算例を示し，本論文で提案する手法の妥当性を検証する．数值計算例 1 では 2 次元ポアズイユ 流れを示し，レベルセット関数の零等位面に埋め込み境界法を適用した流れ解析が妥当であることを示す。次に， 全圧損失最小化のトポロジー最適化の例を示す．数值計算例 2 では絞り管のモデルを示し，本手法により得られる 最適構造の流れ場の妥当性について検証する. 数值計算例 3 では固定設計領域 $D$ において非設計領域を定義した $\mathrm{U}$ 字管のモデルを示す. 数值計算例 4 では 3 次元に拡張した流出口選択問題に対してレイノルズ数 Re の違いによ り異なる最適構造が得られることを示す。ここで, レイノルズ数 $\operatorname{Re}$ は, 平均流速 $U(\mathrm{~m} / \mathrm{s})$, 代表長さ $L(\mathrm{~m})$, 動粘 性係数 $v\left(\mathrm{~m}^{2} / \mathrm{s}\right)$ として $R e=(U L) / v$ と定義する.また，すべての数值計算例において密度 $\rho=1.0 \mathrm{~kg} / \mathrm{m}^{3}$ とする.

数值計算例 2,3 ならびに 4 において, 固定設計領域 $D$ における形状変更領域の初期状態は, 空孔は設けること なく流体で満たされているように設定するため，これらの領域でレベルセット関数の初期值は 1 とする. 本手法 では感度解析にトポロジー導関数を用いており，最適化の過程で空孔の生成や消失といった形態変化を許容する ため, レベルセット関数の初期值で空孔の考慮は行わない.

また，レベルセット関数の更新のために時間発展方程式において用いる仮想時間 $t_{v}$ の更新ステップ幅 $\delta t_{v}$ は，数 值計算例ごとに設定する．時間発展方程式の数值解法は，オイラー陰解法による手法を用いているため，更新ス テップ幅 $\delta t_{v}$ に対して無条件安定である．さらに，更新ステップ幅 $\delta t_{v}$ に対して得られる最適構造に大きな依存関 係がないことは, 文献 (Yamada et al., 2011) において検証されている. そこで, 本論文で示す数值計算例において は，いくつかの更新ステップ幅 $\delta t_{v}$ による検証を実施し，最適化の過程で目的関数値が大幅に振動しない程度の更 新ステップ幅 $\delta t_{v}$ を採用する。

レベルセット関数の零等位面において埋め込み境界法を適用するために，式 (30) ならびに式 (31) に示す補間関 数の係数は，IB 要素ごとに決定されるが，最小二乗法によりこれらの係数を計算するために，IB 要素に対してそ の近傍要素の範囲の指定が必要となる. 本論文で示す数值計算例においては, 2 次元の場合は要素面積の 2 乗根, 3 次元の場合は要素体積の 3 乗根の長さを基準值とし, IB 要素の要素中心から, その基準值の 3.5 倍の距離を近 傍要素の範囲とする. なお, 数值計算例で用いたメッシュモデルは, 面積または体積が概ね同等の要素を用いて おり，計算結果の検証により妥当な流れ場が得られていることが確認できているので，近傍要素の範囲は適切で あると考えている. また, 補間関数の係数 $E_{1}, \boldsymbol{E}_{2}$ は, 流速の勾配に寄与しているが, ディリクレ型の境界条件と して零等位面において流速 0 を規定しており, 数值計算例では層流域の流れを扱っているため，すべての IB 要素 で概ね同じオーダーとなると考えられる。しかしながら，静圧の值は流路の至る所で異なり，ノイマン型の境界 条件として零等位面の法線方向に対して静圧勾配が 0 となるように規定しているため，補間関数の係数は，IB 要 素ごとに異なると考えられる.

\section{$5 \cdot 2$ 数值計算例 $1: 2$ 次元ポアズイユ流れ}

数值計算例 1 として理論解の存在する 2 次元のポアズイユ流れに対してレベルセット関数の零等位面を壁面と した流れ場の解析について考える。そこで，ケース $1:$ 理論解による流れ場，ケース $2:$ 多孔質体による仮想的な 外力を考慮した流れ場，ケース 3 : 埋め込み境界法を適用した流れ場の 3 つのケースについて数值流体解析の結果 を比較検討し，レベルセット関数の零等位面に埋め込み境界法を適用した手法が有効であることを示す.

図 4 に示すように原点 $O$ において $x_{1}$ 方向に対して管長さを $L$ とし， $x_{2}= \pm H / 2$ においてレベルセット関数の零 等位面を配置する. また，静圧を $p$ として $x_{1}$ 成分の流速を $u_{1}, x_{2}$ 成分の流速 $u_{2}=0$ とする. このとき流速の境 界条件は $x_{2}=-H / 2$ および $x_{2}=H / 2$ において $u_{1}=0, x_{1}=0$ において $u_{1}=1 /(2 v)\left(H / 2-x_{2}\right)\left(H / 2+x_{2}\right), x_{1}=L$ において $d u_{1} / d x_{1}=0$ とする. また静圧の境界条件は, $x_{1}=0$ において $d p / d x_{1}=0, x_{2}=-H / 2$ よび $x_{2}=H / 2$ において $d p / d x_{2}=0$ とし， $x_{1}=L$ において $p=0.0$ とする. このときに流れ場の理論解は次式で表される.

$$
\begin{aligned}
& u_{1}\left(x_{1}, x_{2}\right)=-\frac{1}{2 v} \frac{d p}{d x_{1}}\left(\frac{H}{2}-x_{2}\right)\left(\frac{H}{2}+x_{2}\right) \\
& p\left(x_{1}, x_{2}\right)=P-x_{1}
\end{aligned}
$$

数值計算では $L=10.0 \mathrm{~m}, H=1.0 \mathrm{~m}, \quad v=1.0 \mathrm{~m}^{2} / \mathrm{s}$ ならびに $P=10.0 \mathrm{~Pa}$ を設定する．また，メッシュモデル 
は図 5 のように断面 $A-a$ より斜線の要素が配置されており, 断面 $B-b$ では流体領域における壁面近傍の要素が レベルセット関数の零等位面と交差している.

図 4 に示すように $x_{1}=L / 4$ における断面 $A-a$ ならびに $x_{1}=L / 2$ における断面 $B-b$ の 2 つ断面での流れ場に ついて 3 つのケースの数值計算結果を比較する. 各断面における流速と静圧を比較したグラフを図 6 ならびに図 7 に示す.ケース 2 の仮想的な外力を用いた場合, 流速については $x_{2}=0$ の軸上で理論值との相対誤差が $4 \%$ 程度で あるが，壁面近傍において相対誤差は著しく大きくなり $10 \%$ 超えている.さらに，静圧に関しては固体領域でも 静圧の值が 0 とならず流れに起因した静圧が分布しており, 流体領域における理論值との相対誤差も最大で $8 \%$ 程 度である.これに対してケース 3 の埋め込み境界法を適用した流れ場では, 流速に関しては壁面近傍も含めて理論 值との相対誤差が $1 \%$ 程度である. また, 固体領域では静圧の值は 0 であり, 流体領域における理論值との相対誤 差は最大で $3 \%$ となり, 流速ならびに静圧の理論值との相対誤差はケース 2 より もさくなることが確認できる.

以上の検証により埋め込み境界法を適用した流机場の解析は, 仮想的な外力を用いた場合よりも理論值に近い 流れ場を計算できると考えられる.さらに, 流速については壁面近傍において精度よく計算でき, 要素がレベル セット関数の零等位面と交差しても精度に影響を及ぼさないと考えられる.

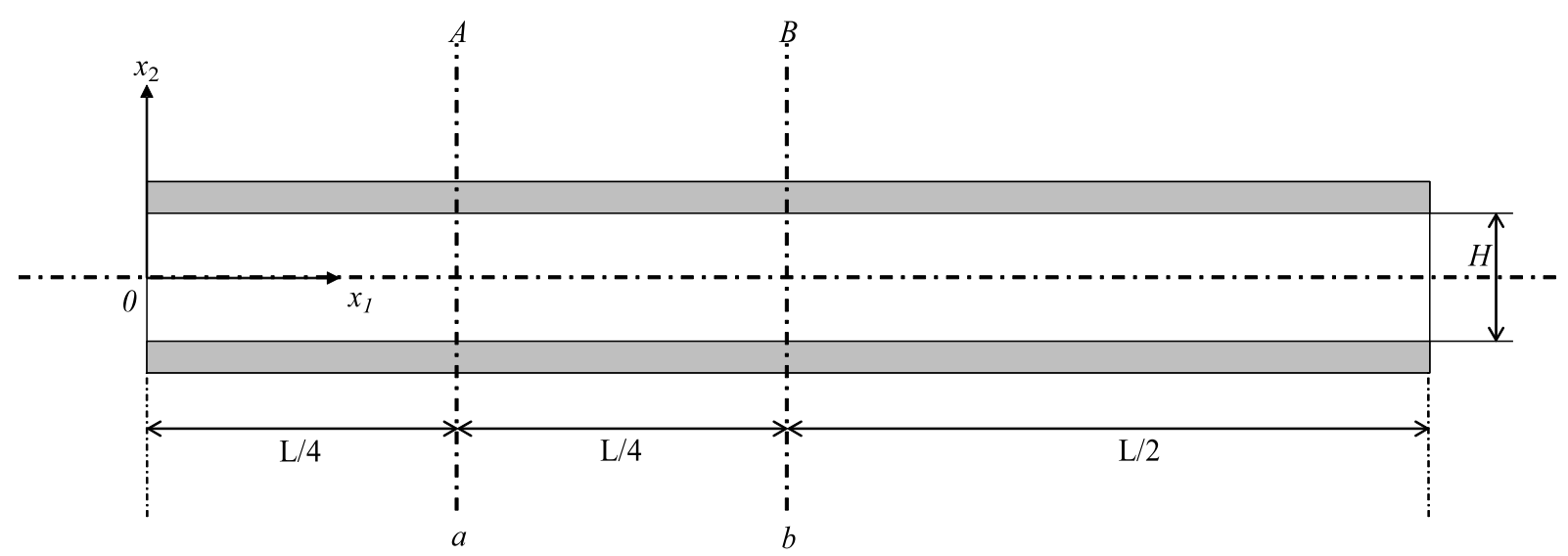

Fig. 4 Poiseuille flow in 2D

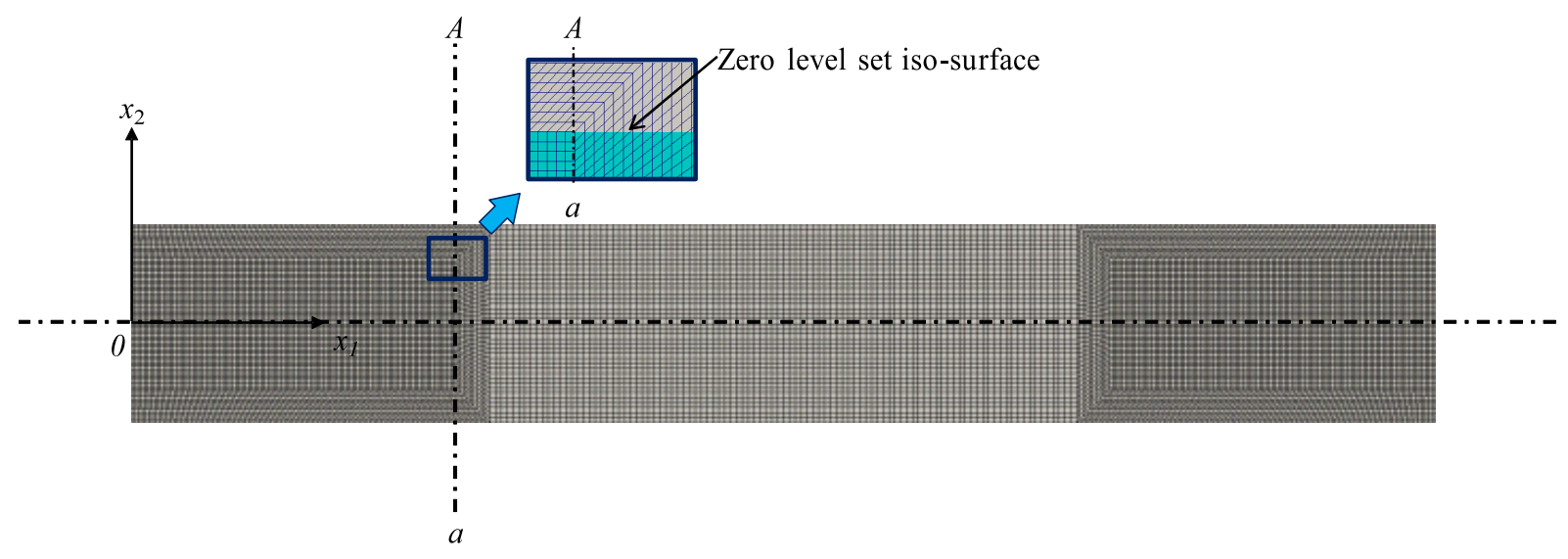

Fig. 5 Computational grid of Poiseuille flow in 2D 


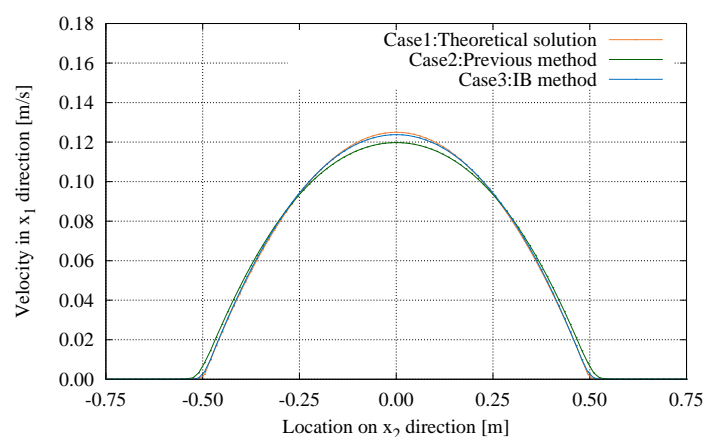

(a) Velocity

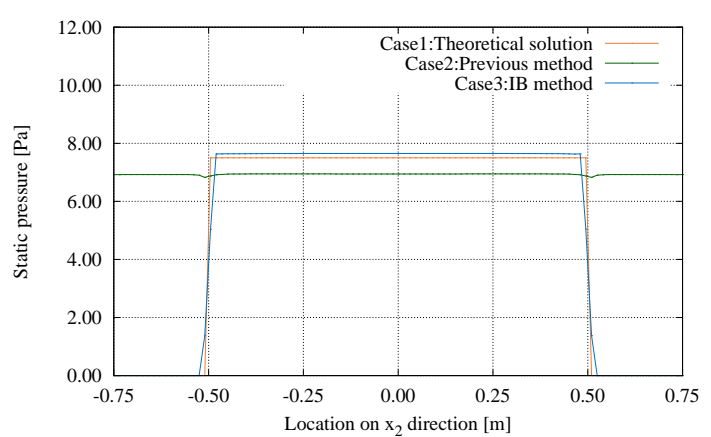

(b) Static pressure

Fig. 6 Velocity and static pressure at A-a section

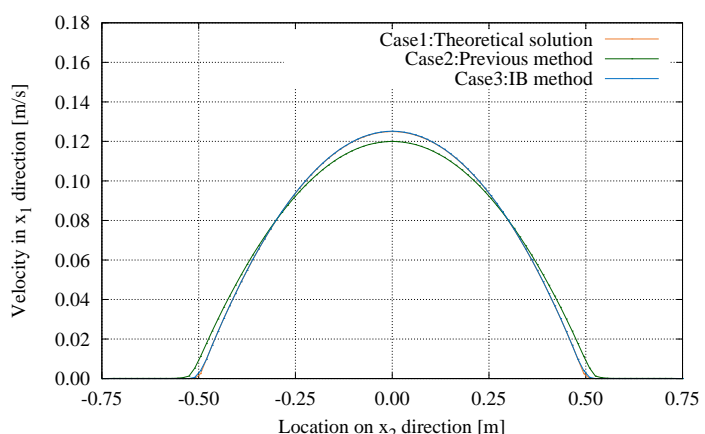

(a) Velocity

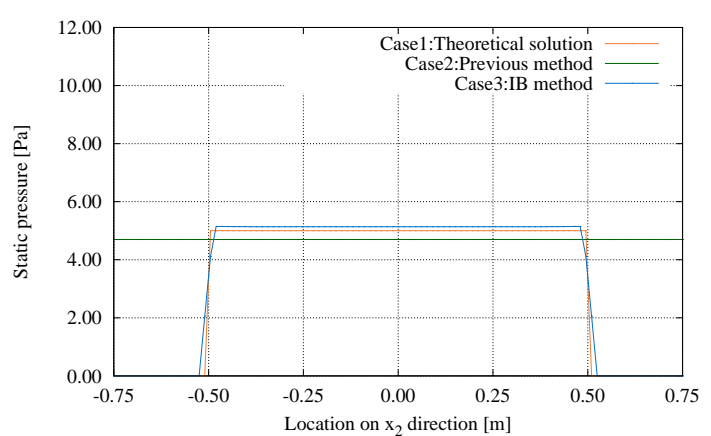

(b) Static pressure

Fig. 7 Velocity and static pressure at B-b section

\section{3 数值計算例 $2:$ 絞り管}

数值計算例 2 としてレイノルズ数 $R e=1.0$ とした絞り管を示す.ここでは, 流路体積の上限を固定設計領域 $D$ の $40 \%$ とする.この数值計算例における固定設計領域 $D$ を図 8(a) に示し, 図 9 に数值計算で用いたメッシュモデル を示す. 固定設計領域 $D$ において $L=1.0 \mathrm{~m}$ とし, 領域内部はすべて四辺形要素で構成し, その要素数は 14080 と する. 境界条件として流入側では $u_{1}=6\left(L / 2-x_{2}\right)\left(L / 2+x_{2}\right)$ となる流速 (すなわち流入側で平均流速 $U=1.0 \mathrm{~m} / \mathrm{s}$ となるように) を規定し, 流出側では $P=0.0 \mathrm{~Pa}$ を規定する. 最適化に必要なパラメータとして正則化係数 $\tau=5.0$ とし，レベルセット関数の初期值は $\phi=1.0$ とする. またレベルセット関数更新のための時間発展方程式で用いる 仮想時間 $t_{v}$ の更新ステップ幅 $\delta t_{v}=1.0 \times 10^{-4}$ とする.

この数值計算例で得られた最適構造を図 8(b) の白色領域で示す. 次に, 得られた最適構造をケース 1 とし, さ らに固定設計領域から最適構造を抽出することで得られた形状モデルをケース 2 として, 図 8(a) に示す断面 $A-a$ ならびに断面 $B-b$ におけるこれら 2 つースの流れ場を比較し, 最適構造での流れ場が妥当であることを示す. なお, ケース 2 では, ケース 1 と同等の要素サイズとなるように, 図 9(b) に示すようなメッシュモデルを構築し, その要素数は 7760 とする.

はじめに, 断面 $A-a$ の流速ならびに静圧のグラフを図 10 に示し, 断面 $B-b$ の流速ならびに静圧のグラフを 図 11 に示す.これらのグラフでは横軸に断面上の座標值を示し, 縦軸に流速または静圧の值を示す.グラフに示 されるケース 1 とケース 2 の解析結果を比較すると流速ならびに静圧の值はほぼ一致しており, 埋め込み境界法 
による零等位面上の流速と静圧の取り扱いが妥当であると考えられる.

次に，流速ならびに静圧のコンターを図 12 ならびに図 13 に示す，ここで，コンターの図中において最適構造の 境界は白色の点線で示す. 先行研究 (古口他,2015) においてケース 1 の最適構造の流れ場は, 固体領域も含む固定 設計領域 $D$ に対して静圧が分布する不適切な結果となる。これに対して本論文による手法を適用することで，図 12(a) ならびに図 13(a) に示すように，ケース 1 においては最適構造となる流体領域のみに適切な流れ場が得られ ており，図 12(b) ならびに図 13(b) に示すケース 2 の流れ場とほぼ一致している。この結果により，埋め込み境界 法により境界条件を考慮することで，最適構造内部において特に静圧分布の適切な評価が可能となることが本提 案手法の大きな利点であると考えている.

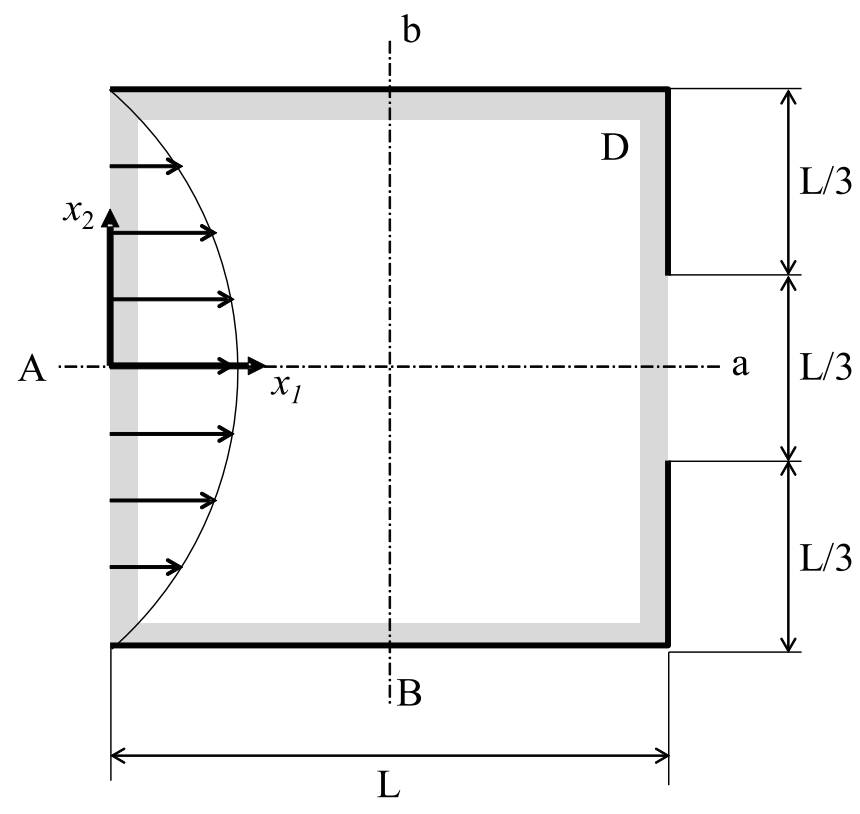

(a) Design domain

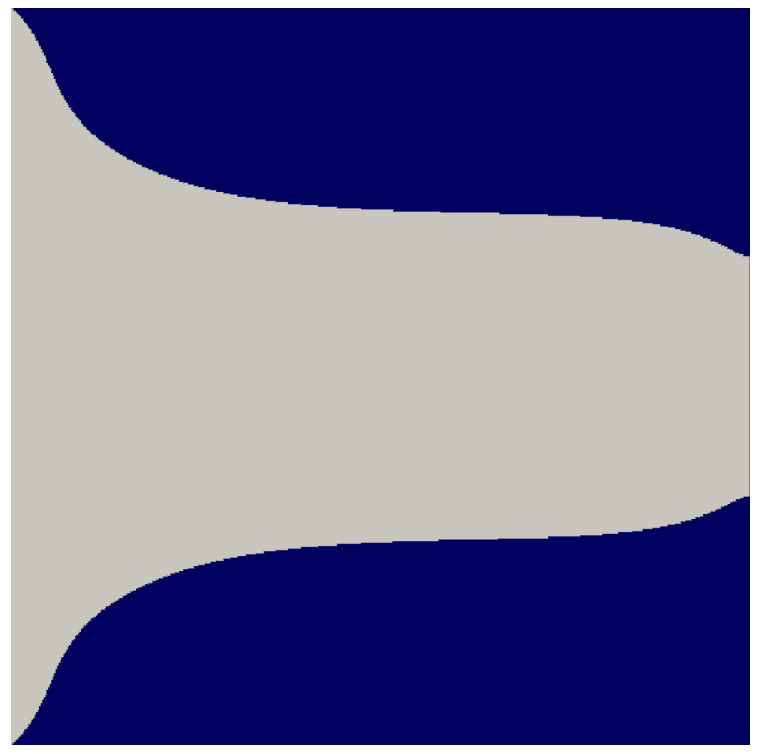

(b) Optimized configuration

Fig. 8 Design domain and optimal configuration for diffuser example

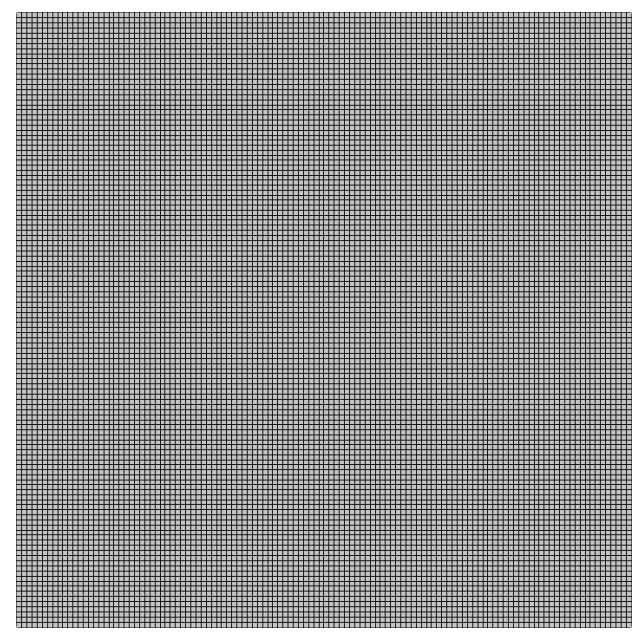

(a) Case1:Topology optimization

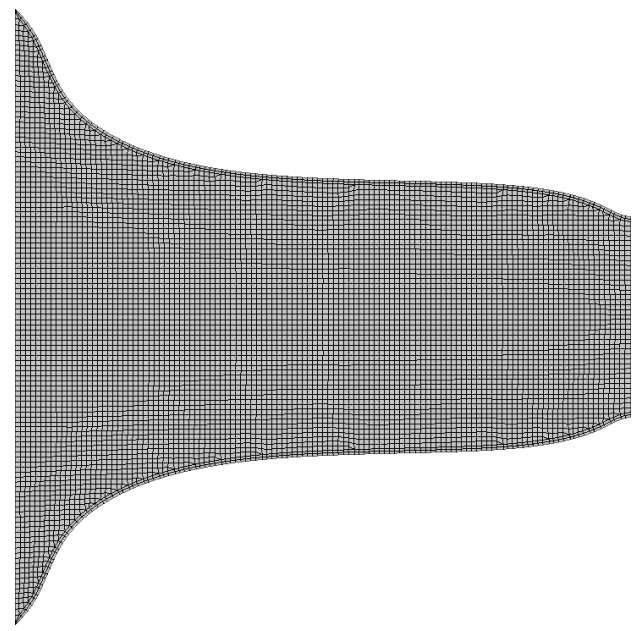

(b) Case2:Extracted structure

Fig. 9 Computational grid of diffuser example 

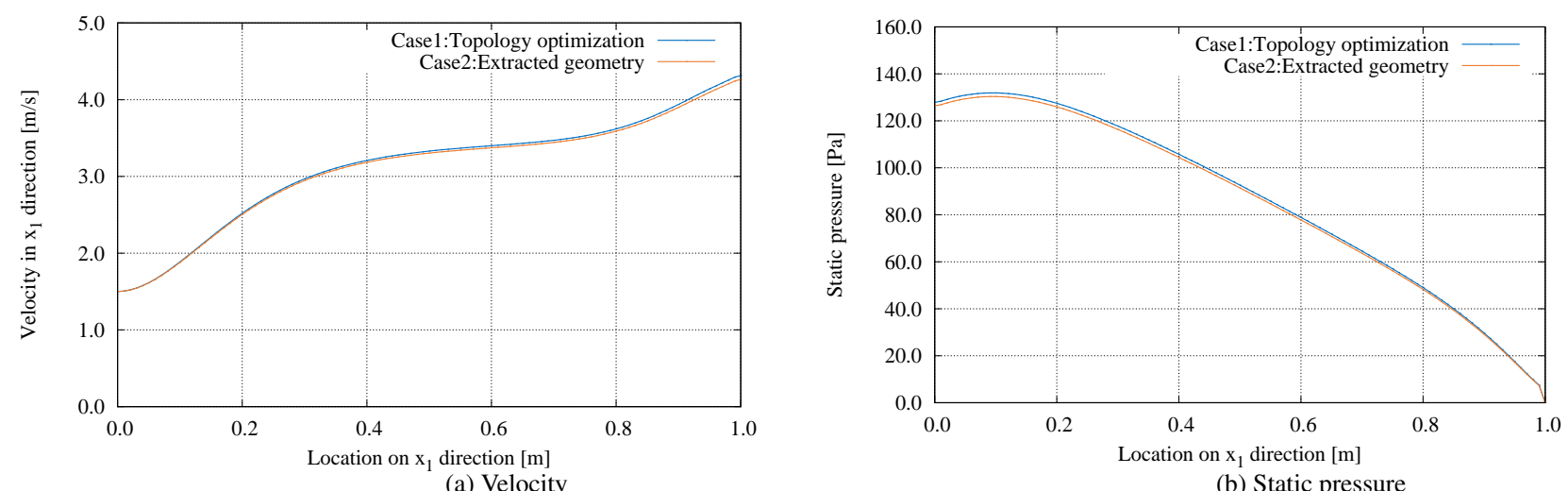

Fig. 10 Velocity and static pressure at A-a section
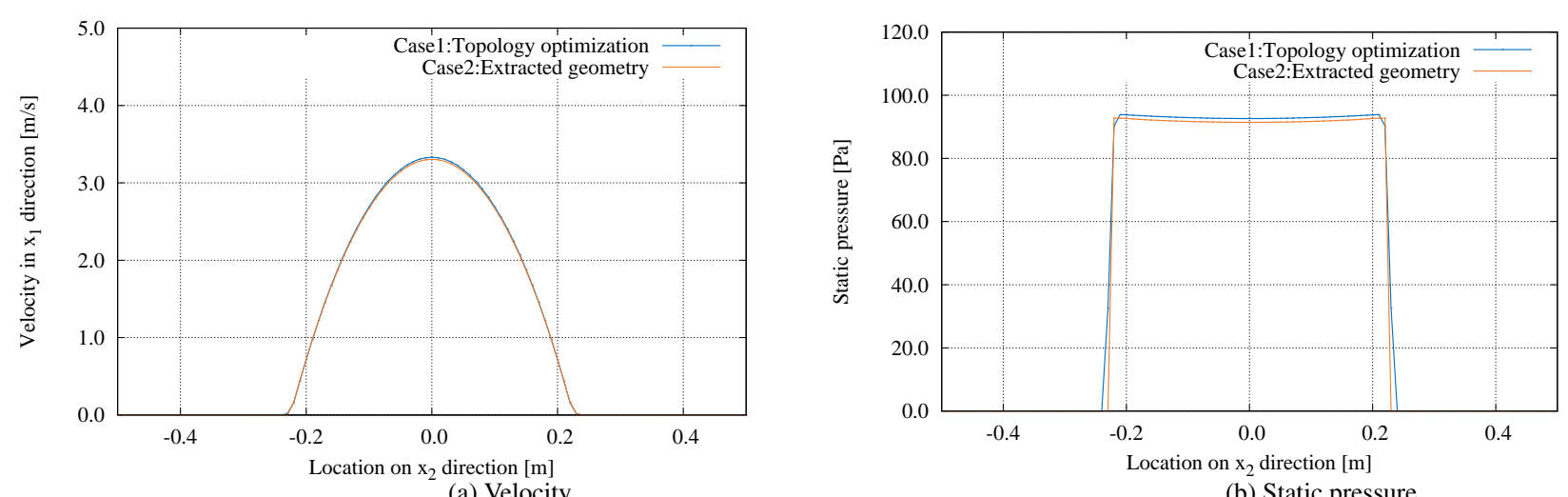

Fig. 11 Velocity and static pressure at B-b section 


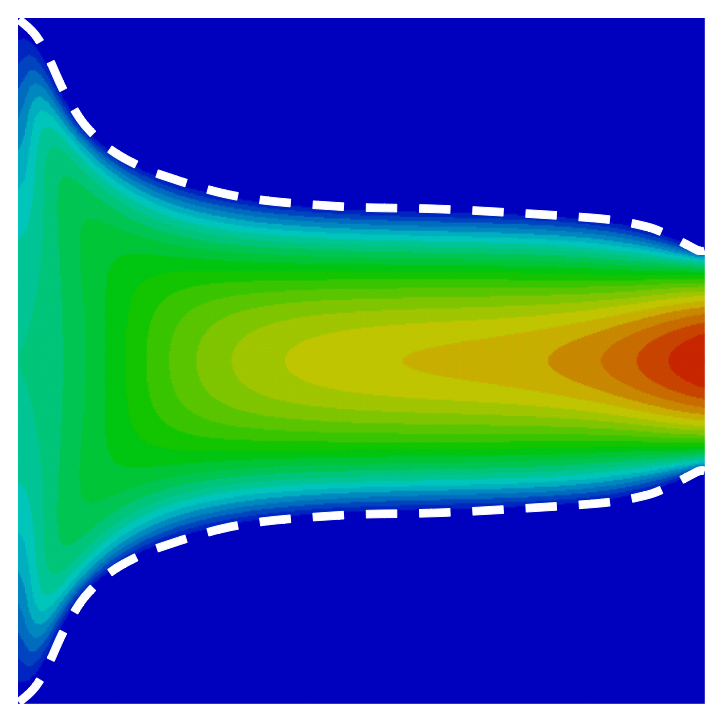

(a) Case1:Topology optimization

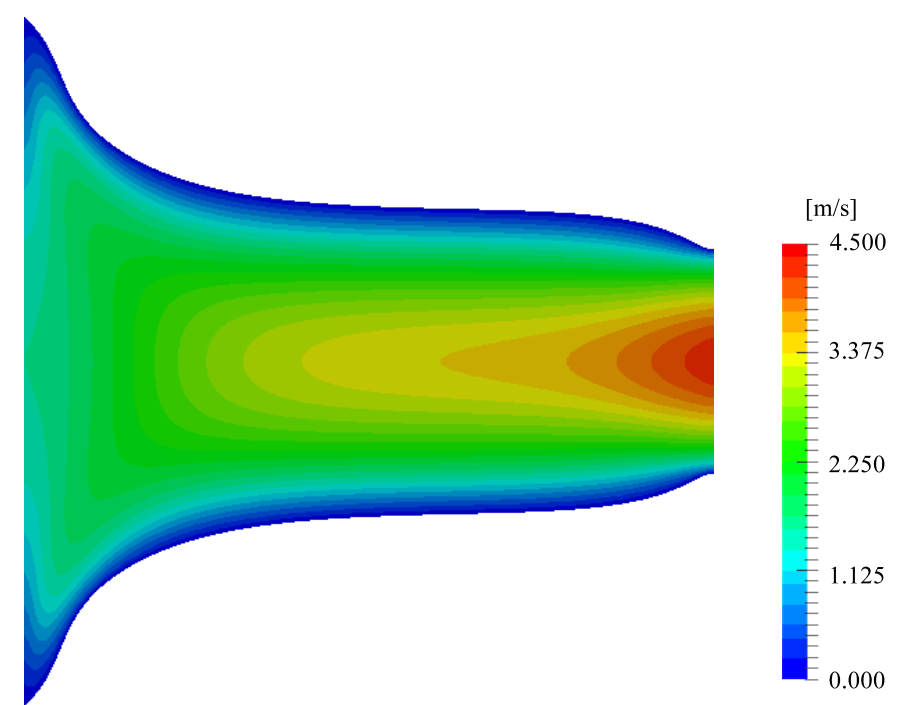

(b) Case2:Extracted structure

Fig. 12 Velocity magnitude distribution in diffuser example

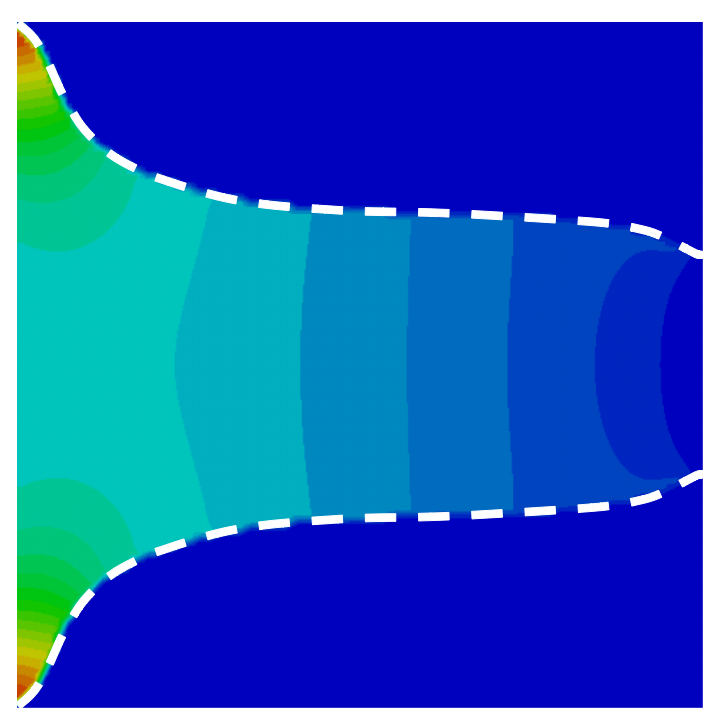

(a) Case1:Topology optimization

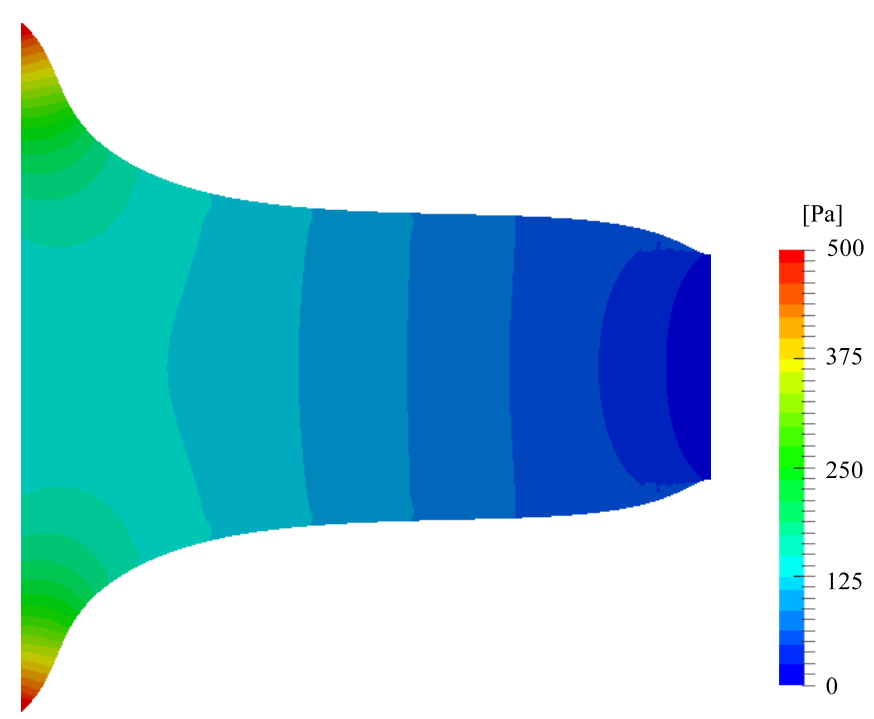

(b) Case2:Extracted structure

Fig. 13 Static pressure distribution in diffuser example

\section{4 数值計算例 $3: \mathbf{U}$ 字管}

数值計算例 3 としてレイノルズ数 $R e=1.0$ とした U 字管を示す. 図 14(a) に示すように, 領域 $D_{N D}$ を非設計領 域とした $\mathrm{U}$ 字型の固定設計領域 $D$ を定義する。この数值計算例で用いたメッシュモデルを図 15 に示す。なお，図 15 における黄色の領域は, 形状変更を伴わない非設計領域 $D_{N D}$ を示す. この数值計算例では流路体積の上限を固 定設計領域 $D$ の $40 \%$ とする. ここで固定設計領域 $D$ において $L=2.0 \mathrm{~m}, H=1.1 \mathrm{~m}, h=0.1 \mathrm{~m}$ とし, 領域内部は すべて四辺形要素で構成され，その要素数は 14520 とする. 境界条件として流入側では $u_{1}=6\left(h / 2-x_{2}\right)\left(h / 2+x_{2}\right)$ となる流速 (すなわち流入側で平均流速 $U=1.0 \mathrm{~m} / \mathrm{s}$ となるように) を規定し，流出側では $P=0.0 \mathrm{~Pa}$ を規定する. 最適化に必要なパラメータとして正則化係数 $\tau=1.0 \times 10^{-1}$ とし， レベルセット関数の初期值は $\phi=1.0$ とする. またレベルセット関数更新のための時間発展方程式で用いる仮想時間 $t_{v}$ の更新ステップ幅 $\delta t_{v}=1.0 \times 10^{-3}$ とする. 
最適構造を図 14(b) に白色領域で示す. 最適構造における流速のコンターを図 16 に示し，静圧のコンターを図 17 に示す. これらのコンターにおいて白色の点線は, 最適構造の境界を示す. 透過抵抗係数 $\alpha$ を設計変数とした 先行研究 (Borrvall and Petersson, 2003) の手法では, $\alpha$ 值の大きさに依っては非設計領域 $D_{N D}$ にも流れ場が分布 することが Kreissl と Maute(Kreissl and Maute, 2012)により報告されている.これに対して本論文による手法を適 用することで, 図 14(a) に示す非設計領域 $D_{N D}$ を流体が透過せず壁面近傍で適切な流れ場を示す最適構造が得ら れると考えられる. また，この数值計算例においても図 16 と図 17 に示すように最適構造の内部にのみ流速なら びに静圧が分布していることを確認しており, 埋め込み境界法により境界条件を考慮することで数值計算例 2 と 同様に適切な流れ場の評価が可能となることが考えられる.

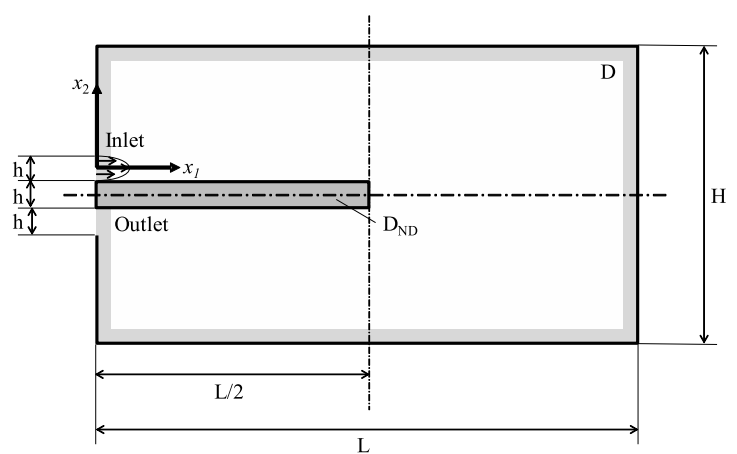

(a) Design domain

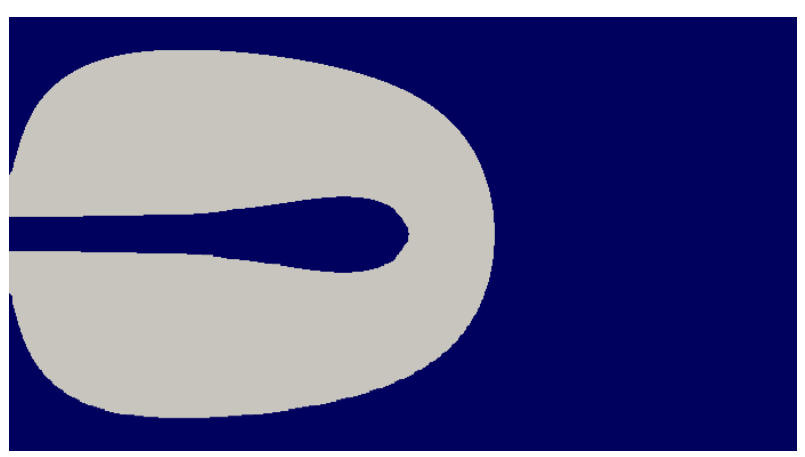

(b) Optimized configuration

Fig. 14 Design domain and optimal configuration for U-bend example

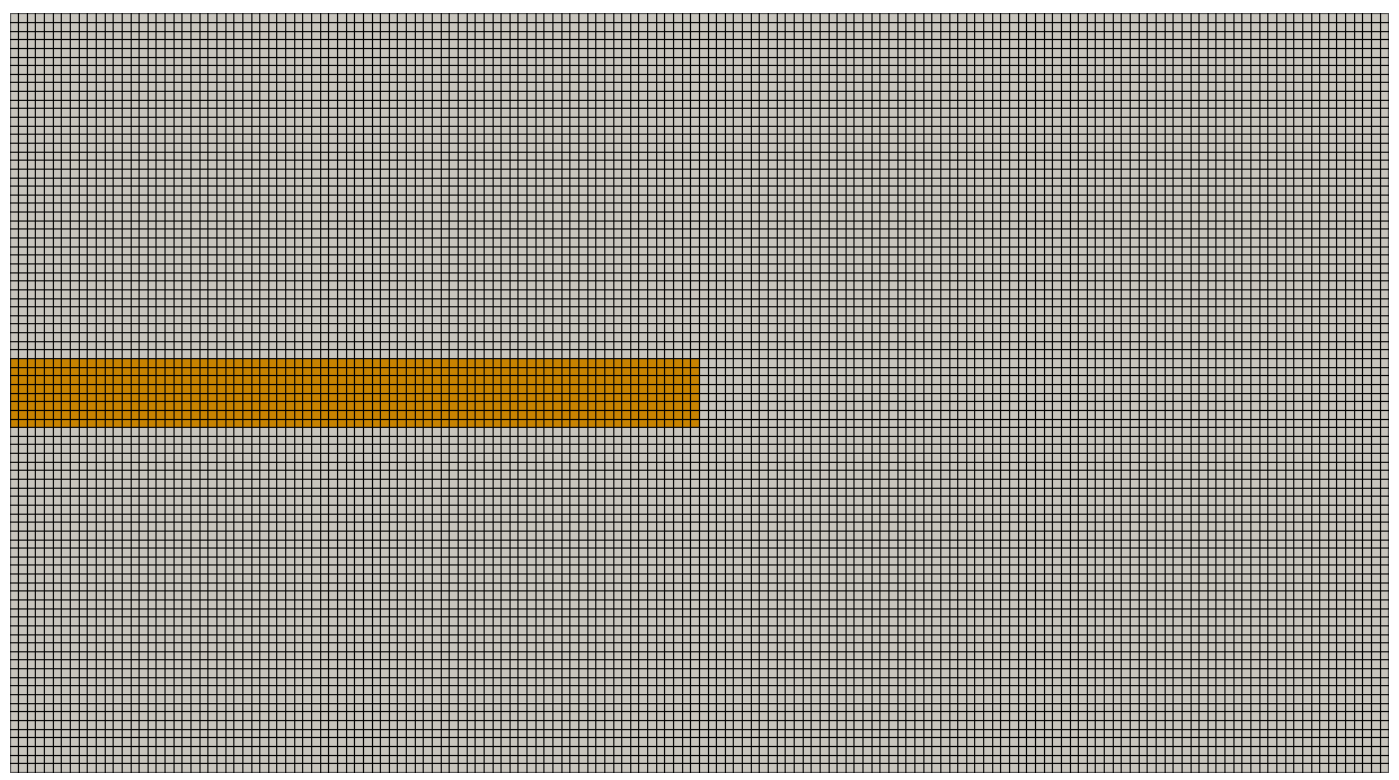

Fig. 15 Computational grid of U-bend example 

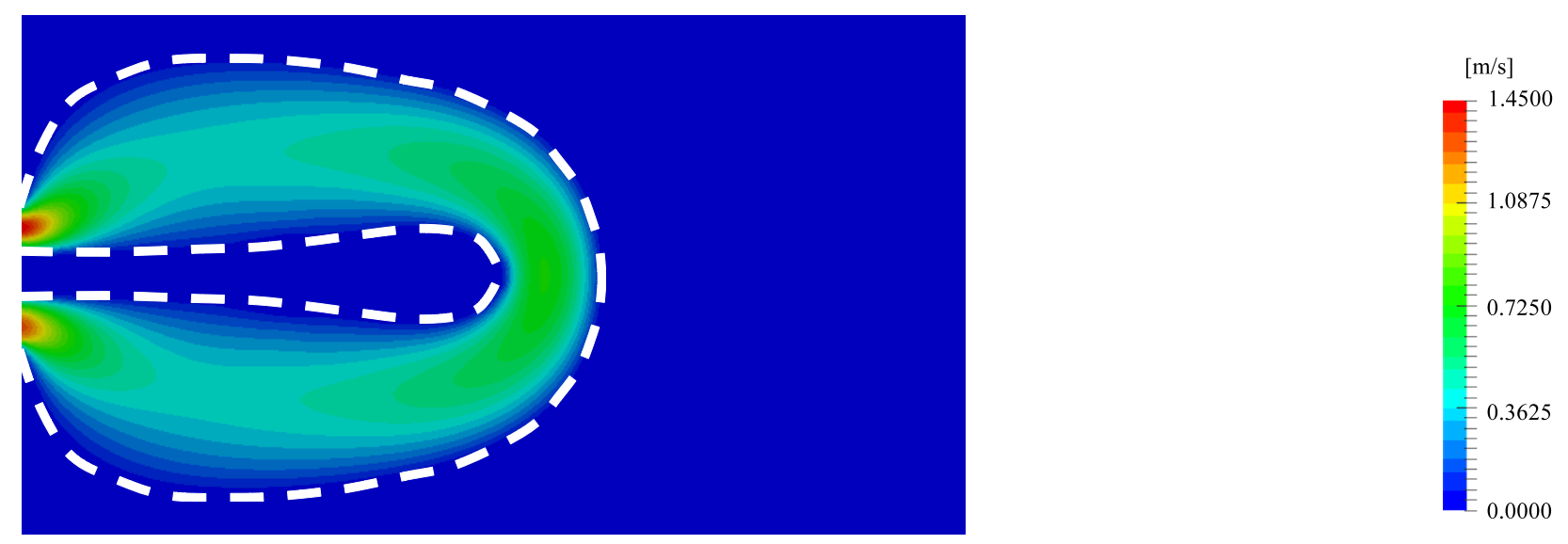

Fig. 16 Velocity magnitude distribution in U-bend example
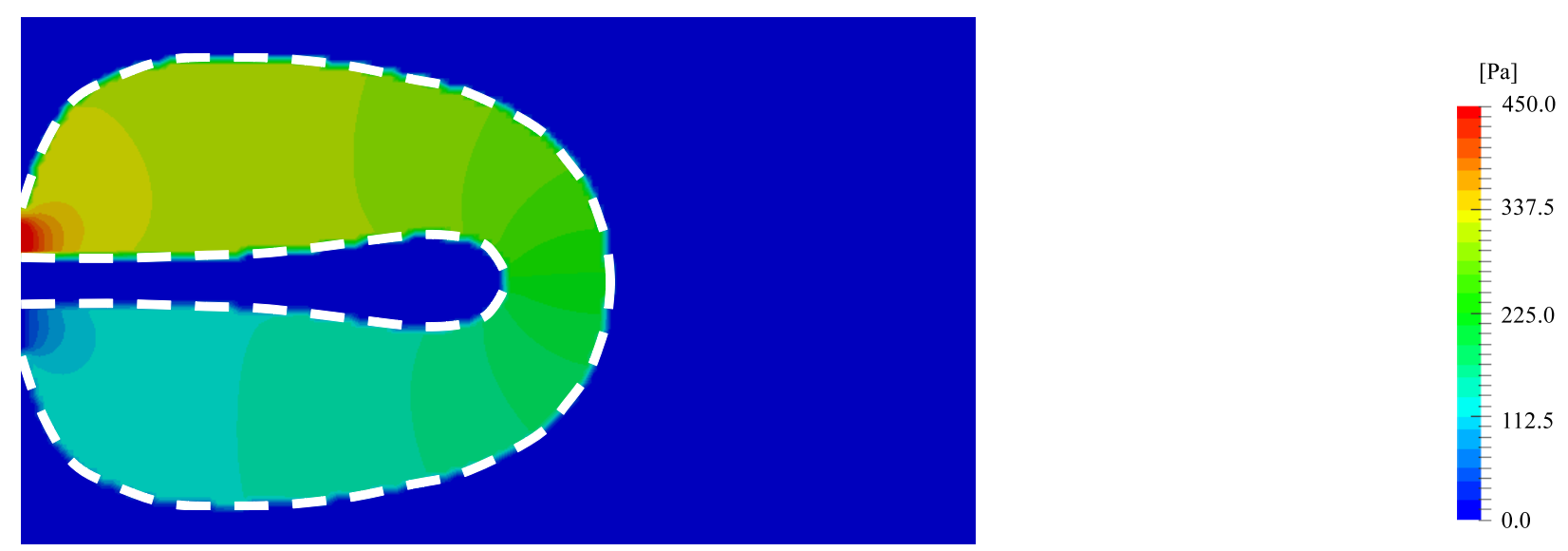

Fig. 17 Static pressure distribution in U-bend example

\section{5 数值計算例 $4: 3$ 次元の流出口選択問題}

最後の数值計算例では異なるレイノルズ数 $R e=1.0$ ならびに $R e=1000.0$ による 3 次元の流路選択問題を示す. この数值計算例では, 流路体積の上限を固定設計領域 $D$ の $15 \%$ とし, レイノルズ数 $R e$ の違いにより最適構造に おいて異なる流出口が選択されることを示す. 固定設計領域 $D$ は, 図 18 に示すように直方体領域とし $L=1.0 \mathrm{~m}$ として 1 つの流入口に対して 2 つの流出口を設定する.メッシュモデルは, 図 19 に示すように要素数 66208 とし て多面体要素で構成する. 境界条件として流入側 (Inlet) では流速 $U=1.0 \mathrm{~m} / \mathrm{s}$ を規定し, 流出側 (Outlet1,Outlet2) では $P=0.0 \mathrm{~Pa}$ を規定する. 最適化に必要なパラメータとして正則化係数 $\tau=2.5$ とし, レベルセット関数の初期 值は $\phi=1.0$ とする. またレベルセット関数更新のための時間発展方程式で用いる仮想時間 $t_{v}$ の更新ステップ幅 $\delta t_{v}=2.0 \times 10^{-3}$ とする.

レイノルズ数 $R e=1.0$ の最適構造（図 20）は流体の粘性が大きいため流入口に近い流出口 Outlet1 が選択される が, レイノルズ数 $R e=1000.0$ の最適構造（図 21）は流体の慣性が大きくなるため流入口から遠い流出口 Outlet 2 が選択される.レイノルズ数の違いにより得られる最適構造は, 先行研究 (古口他, 2015) と同等の構造が得られて いる. さらに流れ場については, 最適構造内部のみに分布することを確認しており, 固体領域も含む固定設計領域 $D$ に静圧が分布する欠点を持つ先行研究 (古口他, 2015) の手法と比較して大幅に改善されていると考えている. な お, 流れ場の妥当性を検証するために固定設計領域 $D$ より最適構造と同等の形状を抽出し, 同等の解像度による メッシュモデルを用いて，これら 2 つモデルの流れ場の比較検証を実施した。 その結果, レイノルズ数 $R e=1.0$ の流れ場について比較した場合，ほぼ同等であることが確認できた。これに対して，レイノルズ数 Re=1000.0の 最適構造に関して比較検証したところ, 埋め込み境界法を適用した本手法による流れ場解析では, 流れが速く静 
圧が高めに分布する傾向がみられた。しかしながら，2つのモデルの流れ場の比較により, 流速ならびに静圧は, ほぼ同等のオーダーで得られていることを確認している．したがって，この数值計算例におけるメッシュ解像度 は十分であり，本論文で提案する手法は，層流域の流れを対象として概ね適用可能であると考えられる．さらに 高いレイノルズ数の流れに対して, 本提案手法を適用するためには, 壁法則や乱流モデルの適用も含めた検討が 必要であり, 今後の課題であると考えている.

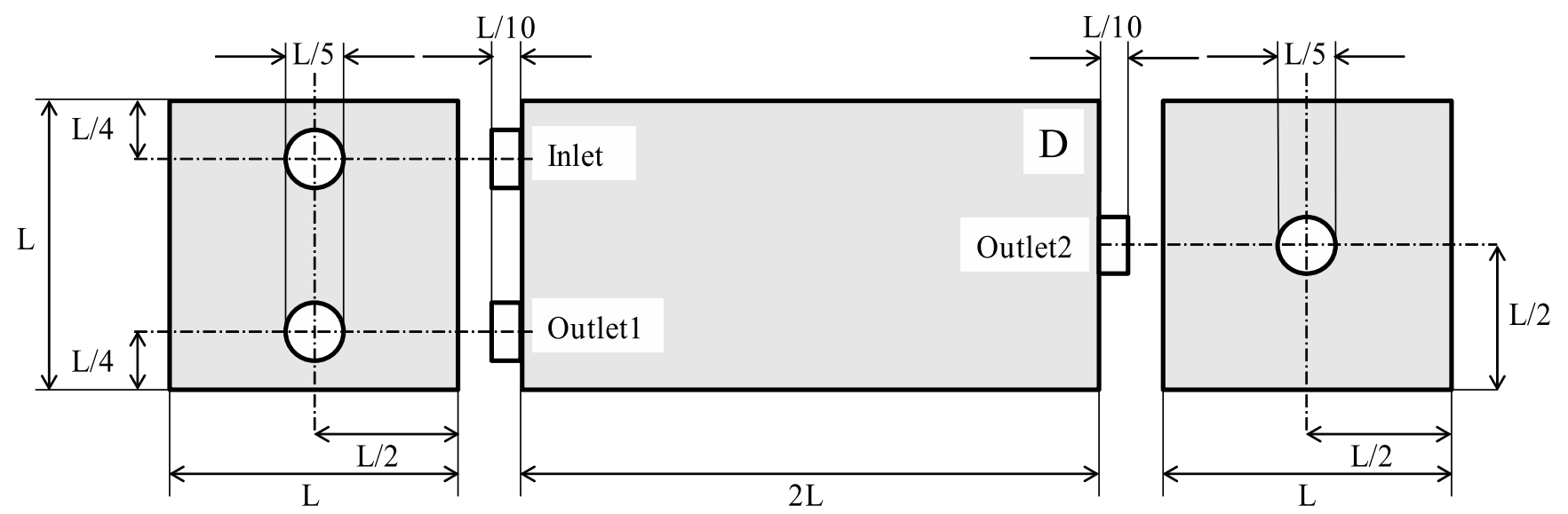

Fig. 18 Design domain for switching pipe example
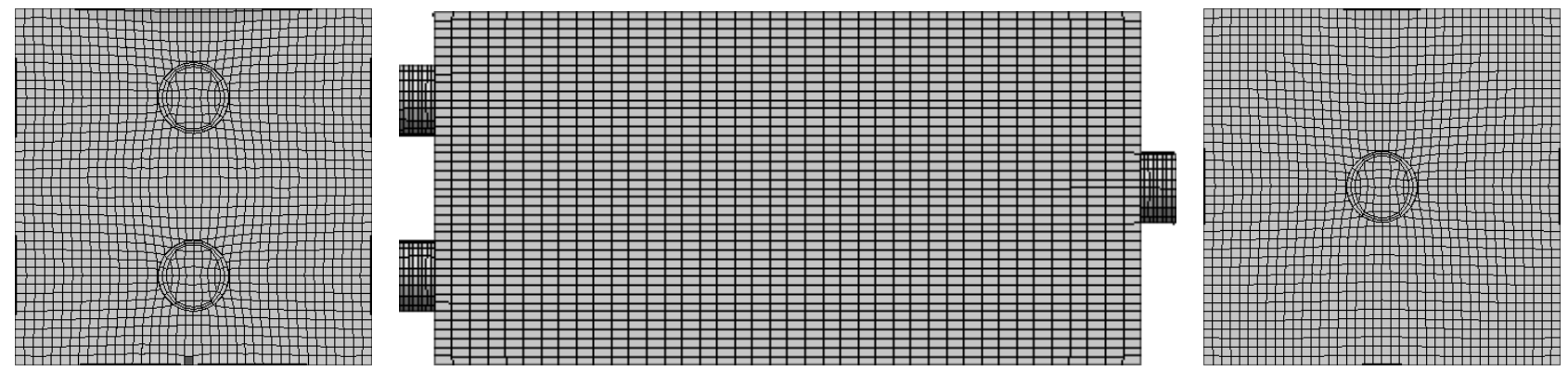

Fig. 19 Computational grid of switching pipe example
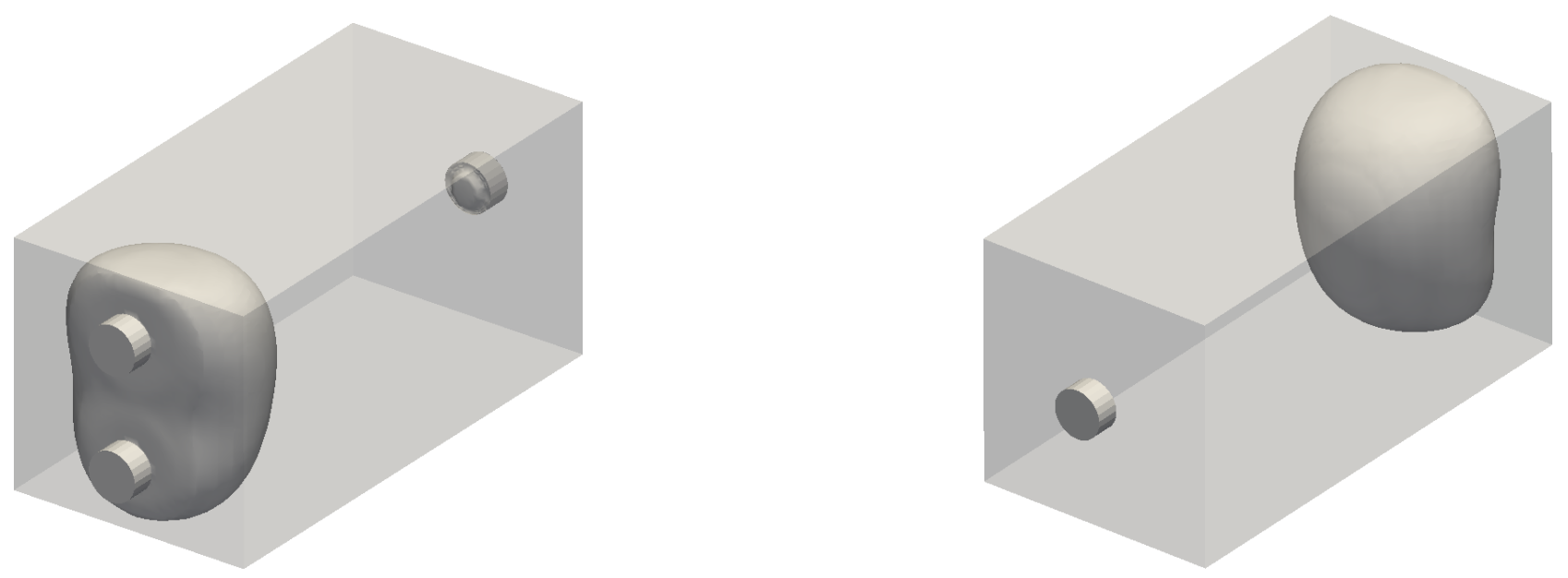

Fig. 20 Optimized configuration in case of $\mathrm{Re}=1.0$ 

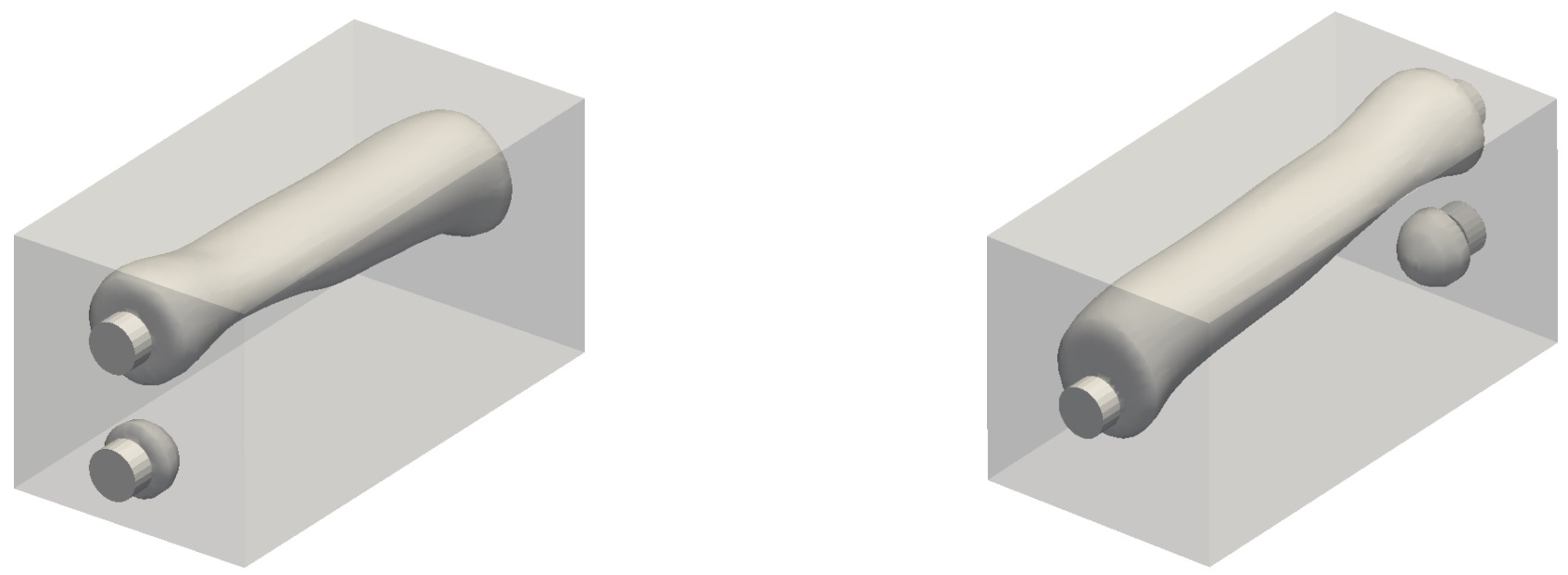

Fig. 21 Optimized configuration in case of $\mathrm{Re}=1000.0$

6. 結言

本論文では，レベルセット法による境界表現を用いて定常の非圧縮性粘性流れを対象としたトポロジー最適化 の手法を提案した. 本論文により得られた結果を以下に示す.

(1) 先行研究における壁面の取り扱いに関する問題点を指摘し, その解決手法として埋め込み境界法による壁面 近傍の流れ場の取り扱い手法を提案した。

(2) 最適化の過程で必要な設計感度にはトポロジー導関数を適用した。

(3) 固定設計領域において，レベルセット関数の零等位面におけるディリクレ型およびノイマン型の境界条件を 考慮して埋め込み境界法により壁面近傍の流れ場を数值的に解析する手法を示した.

(4) 状態方程式ならびに随伴方程式は, 有限体積法により離散化し，その数值解析には SIMPLE 法を適用した。ま た，レベルセット関数の更新手法として時間発展方程式の数值解析にはオイラー陰解法を適用した。

(5) 数值計算例を示すことで本論文で提案する手法の有効性を示した. はじめに, 2 次元のポアズイユ流れの理論 解と埋め込み境界法を適用して得られた流れ場を比較し, 理論解と同等の流れ場が得られることを確認した. 次に, 全圧損失の最小化問題として絞り管とU 字管の数值計算例に対して妥当な最適構造が得られることを 示し，3 次元モデルにおいて異なるレイノルズ数に対して既報と同等な最適構造が得られることを示した。

\section{文献}

Allaire, G., de Gournay, F., Jouve, F. and Toader, A.M., Structural optimization using topological and shape sensitivity via a level set method, Control and Cybernetics, Vol.34, Issue 1 (2005), pp.59-80.

Amstutz, S., The topological asymptotic for the Navier-Stokes equations, ESAIM: Control, Optimisation and Calculus of Variations, Vol.11, No.3 (2005), pp.401-425.

Bendsøe, M. P. and Kikuchi, N., Generating optimal topologies in structural design using a homogenization method, Computer Methods in Applied Mechanics and Engineerings, Vol.71, No.2 (1988), pp.197-224.

Berger, M. and Aftosmis, M. J., Progress towards a Cartesian cut-cell method for viscous compressible Flow, 50th AIAA Aerospace Sciences Meeting (2012), p.2012-1301.

Borrvall, T. and Petersson, J., Topology optimization of fluids in Stokes flow, International Journal for Numerical Methods in Fluids, Vol.41, No.1 (2003), pp.77-107.

Challis, V. J. and Guest, J. K., Level set topology optimization of fluids in Stokes flow, Numerical Methods in Engineering, Vol. 79, Issue 10 (2009), pp.1284-1308.

Deng, Y., Liu, Z., Wu, J. and Wu, Y., Topology optimization of steady Navier-Stokes flow with body force, Computer Methods in Applied Mechanics and Engineering, Vol.255 (2013), pp.306-321. 
Gersborg-Hansen, A., Sigmund, O. and Haber, R. B., Topology optimization of channel flow problems, Structural and Multidisciplinary Optimization, Vol.30, Issue 3 (2005), pp 181-192.

Guest, J. K. and Prévost, J. H., Topology optimization of creeping fluid flows using Darcy-Stokes finite element, International Journal for Numerical Methods in Engineering, Vol.66, Issue 3 (2006), pp.461-484.

古口睦士, 矢地謙太郎, 山田崇恭, 泉井一浩, 西脇眞二, 有限体積法を用いたレベルセット法に基づく非圧縮性粘性流 れのトポロジー最適化, 日本計算工学会論文集 (2015), p.20150002.

Kreissl, S. and Maute, K., Levelset based fluid topology optimization using the extended finite element method, Structural and Multidisciplinary Optimization, Vol.46, Issue 3 (2012), pp.311-326.

Kubo, S., Yaji, K., Yamada, T., Izui, K. and Nishiwaki, S., A level set-based topology optimization method for optimal manifold designs with flow uniformity in plate-type microchannel reactors, Structural and Multidisciplinary Optimization, Vol.55, Issue 4 (2017), pp.1311-1327.

Majumdar, S., Iaccarino, G. and Durbin, P., RANS solvers with adaptive structured boundary non-conforming grids. Technical report, Center for Turbulence Research, NASA Ames Research Center/Stanford University, Palo Alto, CA (2001).

Mittal, R. and Iaccarino, G., Immersed boundary method, Annual Review of Fluid Mechanics, Vol.37(2005), pp.239-261.

Olesen, L. H., Okkels, F. and Bruus, H., A high-level programming-language implementation of topology optimization applied to steady-state Navier-Stokes flow, International Journal for Numerical Methods in Engineering, Vol.65, Issue 7 (2006), pp.975-1001.

Patanker, S. V., Numerical heat transfer and fluid flow, 1st edn., Taylor \& Francis Publishing (1980).

Peskin, C. S., Flow patterns around heart valves: a numerical method, Journal of Computational Physics, Vol.10, Issue 2 (1972), pp.252-271.

Yamada, T., Izui, K., Nishiwaki, S. and Takezawa, A., A Topology optimization method based on the level set method incorporating a fictitious interface energy, Computer Methods in Applied Mechanics and Engineering, Vol.199, Issues 45-48 (2010), pp.2876-2891.

Yamada, T., Izui, K. and Nishiwaki, S., A Level set-based topology optimization method for maximizing thermal diffusivity in problems including design-dependent effects, Journal of Mechanical Design, Vol.133, Issues 3 (2011), p.031011.

Zhou, S. and Li, Q., A variational level set method for the topology optimization of steady-state Navier-Stokes flow, Journal of Computational Physics, Vol.227, Issue 24 (2008), pp.10178-10195.

\section{References}

Allaire, G., de Gournay, F., Jouve, F. and Toader, A.M., Structural optimization using topological and shape sensitivity via a level set method, Control and Cybernetics, Vol.34, Issue 1 (2005), pp.59-80.

Amstutz, S., The topological asymptotic for the Navier-Stokes equations, ESAIM: Control, Optimisation and Calculus of Variations, Vol.11, No.3 (2005), pp.401-425.

Bendsøe, M. P. and Kikuchi, N., Generating optimal topologies in structural design using a homogenization method, Computer Methods in Applied Mechanics and Engineerings, Vol.71, No.2 (1988), pp.197-224.

Berger, M. and Aftosmis, M. J., Progress towards a Cartesian cut-cell method for viscous compressible Flow, 50th AIAA Aerospace Sciences Meeting (2012), p.2012-1301.

Borrvall, T. and Petersson, J., Topology optimization of fluids in Stokes flow, International Journal for Numerical Methods in Fluids, Vol.41, No.1 (2003), pp.77-107.

Challis, V. J. and Guest, J. K., Level set topology optimization of fluids in Stokes flow, Numerical Methods in Engineering, Vol. 79, Issue 10 (2009), pp.1284-1308.

Deng, Y., Liu, Z., Wu, J. and Wu, Y., Topology optimization of steady Navier-Stokes flow with body force, Computer Methods in Applied Mechanics and Engineering, Vol.255 (2013), pp.306-321.

Gersborg-Hansen, A., Sigmund, O. and Haber, R. B., Topology optimization of channel flow problems, Structural and Multidisciplinary Optimization, Vol.30, Issue 3 (2005), pp 181-192. 
Guest, J. K. and Prévost, J. H., Topology optimization of creeping fluid flows using Darcy-Stokes finite element, International Journal for Numerical Methods in Engineering, Vol.66, Issue 3 (2006), pp.461-484.

Koguchi, A., Yaji, K., Yamada, T., Izui, K. and Nishiwaki, S., Level set-based topology optimization in an incompressible viscous flow using the finite volume method, Transaction of JSCES (2015), p.20150002 (in Japanese).

Kreissl, S. and Maute, K., Levelset based fluid topology optimization using the extended finite element method, Structural and Multidisciplinary Optimization, Vol.46, Issue 3 (2012), pp.311-326.

Kubo, S., Yaji, K., Yamada, T., Izui, K. and Nishiwaki, S., A level set-based topology optimization method for optimal manifold designs with flow uniformity in plate-type microchannel reactors, Structural and Multidisciplinary Optimization, Vol.55, Issue 4 (2017), pp.1311-1327.

Majumdar, S., Iaccarino, G. and Durbin, P., RANS solvers with adaptive structured boundary non-conforming grids. Technical report, Center for Turbulence Research, NASA Ames Research Center/Stanford University, Palo Alto, CA (2001).

Mittal, R. and Iaccarino, G., Immersed boundary method, Annual Review of Fluid Mechanics, Vol.37(2005), pp.239-261.

Olesen, L. H., Okkels, F. and Bruus, H., A high-level programming-language implementation of topology optimization applied to steady-state Navier-Stokes flow, International Journal for Numerical Methods in Engineering, Vol.65, Issue 7 (2006), pp.975-1001.

Patanker, S. V., Numerical heat transfer and fluid flow, 1st edn., Taylor \& Francis Publishing (1980).

Peskin, C. S., Flow patterns around heart valves: a numerical method, Journal of Computational Physics, Vol.10, Issue 2 (1972), pp.252-271.

Yamada, T., Izui, K., Nishiwaki, S. and Takezawa, A., A Topology optimization method based on the level set method incorporating a fictitious interface energy, Computer Methods in Applied Mechanics and Engineering, Vol.199, Issues 45-48 (2010), pp.2876-2891.

Yamada, T., Izui, K. and Nishiwaki, S., A Level set-based topology optimization method for maximizing thermal diffusivity in problems including design-dependent effects, Journal of Mechanical Design, Vol.133, Issues 3 (2011), p.031011.

Zhou, S. and Li, Q., A variational level set method for the topology optimization of steady-state Navier-Stokes flow, Journal of Computational Physics, Vol.227, Issue 24 (2008), pp.10178-10195. 